\title{
1 Single nucleus sequencing fails to detect microglial activation in human tissue
}

2 N. Thrupp ${ }^{1,2}$, C. Sala Frigerio ${ }^{1,2,3}$, L. Wolfs ${ }^{1,2}$, N. G. Skene $e^{4}$, S. Poovathingal ${ }^{1,2}$, Y. Fourne ${ }^{1,2}$, P. M. Matthews ${ }^{4}$, T.

3 Theys $^{5}$, R. Mancuso ${ }^{1,2}$, B. de Strooper ${ }^{1,2,3,6^{*}}$, M. Fiers $^{1,2,3^{*}}$

$5 \quad{ }^{I}$ Centre for Brain and Disease Research, Flanders Institute for Biotechnology (VIB), Leuven, Belgium

$6 \quad{ }^{2}$ Department of Neurosciences and Leuven Brain Institute, KU Leuven, Leuven, Belgium

$7 \quad{ }^{3}$ UK Dementia Research Institute at UCL, University College London, London, UK

$8{ }^{4}$ UK Dementia Research Institute at Imperial College London and Department of Brain Science, Imperial College London, London, UK

$9 \quad{ }^{5}$ Department of Neurosciences, Research group experimental neurosurgery and neuroanatomy, KU Leuven, Leuven, Belgium

10 * corresponding authors

$11 \quad{ }^{6}$ lead contact

\section{$13 \underline{\text { Abstract }}$}

14 Single nucleus RNA-Seq (snRNA-Seq) methods are used as an alternative to single cell

15 RNA-Seq methods, as they allow transcriptomic profiling of frozen tissue. However, it is

16 unclear whether snRNA-Seq is able to detect cellular state in human tissue. Indeed, snRNA-

17 Seq analyses of human brain samples have failed to detect a consistent microglial activation

18 signature in Alzheimer's Disease. A comparison of microglia from single cells and single

19 nuclei of four human subjects reveals that $\sim 1 \%$ of genes is depleted in nuclei compared to

20 whole cells. This small population contains $18 \%$ of genes previously implicated in microglial

21 activation, including $A P O E$, CST3, FTL, SPP1, and CD74. We confirm our findings across

22 multiple previous single nucleus and single cell studies. Given the low sensitivity of snRNA-

23 Seq to this population of activation genes, we conclude that snRNA-Seq is not suited to

24 detecting cellular activation in microglia in human disease.

\section{$26 \underline{\text { Keywords }}$}

27 Microglia ; activation; Alzheimer's Disease ; single nucleus RNA-Seq 
32 Single cell approaches allow us to study cell-to-cell heterogeneity (Habib et al., 2017), in

33 brain material however, it is difficult to dissociate individual cells (Habib et al., 2017; Lake et al., 2016). This is further complicated if one is interested in studying the human brain, where often only frozen material is available. One alternative to study cellular transcriptional heterogeneity in brain tissue is single nucleus transcriptomics. Single nucleus RNA-Seq (snRNA-Seq) studies have shown concordance between single cell and single nucleus transcriptome profiles in mice (Bakken et al., 2018; Habib et al., 2017; Lake et al., 2017), but have limited the comparison to the identification of major cell types. It is unclear whether a snRNA-Seq approach is equally effective in identifying dynamic cellular substates such as microglial activation in human tissue.

A recent breakthrough in the field of Alzheimer's Disease (AD) using single cell RNA-Seq (scRNA-Seq) demonstrated clearly that microglia become activated in response to amyloid plaques in mouse models (Keren-Shaul et al., 2017). This response comprises a transcriptional switch to a state called Activation Response Microglia (ARM) (Sala Frigerio et al., 2019), or Disease-Associated Microglia (DAM, MGnD) (Keren-Shaul et al., 2017; Krasemann et al., 2017). Ample evidence suggests that this microglial response is also relevant in human $\mathrm{AD}$ : microglia are believed to play a role in amyloid clearance (Efthymiou and Goate, 2017) and complement-mediated synapse loss (Fonseca et al., 2017), and histological studies have demonstrated considerable microgliosis around plaques in humans (McGeer et al., 1987). In addition, there is significant overlap between those genes involved in the microglial response, and genes within loci carrying AD genetic risk, as identified in Genome-Wide Association Studies (GWAS) (Efthymiou and Goate, 2017; Jansen et al., 2019; Kunkle et al., 2019; Lambert et al., 2013; Marioni et al., 2018), for example, $A P O E$, TREM2, APOC1, CD33 (Sala Frigerio et al., 2019). Most recently, the engrafting of human microglia into AD mouse models, followed by single cell RNA-sequencing, identified 66 DAM genes relevant to human activation ${ }^{15}$, and a bulk RNA-Seq study of AD patients identified 64 DAM genes ${ }^{16}$. In stark contrast, a number of high-profile snRNA-Seq studies of microglia in human AD (Del-Aguila et al., 2019; Grubman et al., 2019; Mathys et al., 2019; 
cluster analysis by Mathys et al. of 48 AD patients and controls reported only 28 of 257

orthologous activation genes in common with the DAM signature (Mathys et al., 2019).

Differential expression analysis between AD and control patients revealed 22 genes upregulated in $\mathrm{AD}$ patients (5 overlapping with the DAM signature). Of these AD genes, only 8 were also upregulated in another snRNA-Seq study of human AD (Grubman et al., 2019), and only 4 were also upregulated in another snRNA-Seq study of AD TREM2 variants (Zhou et al., 2020). The AD TREM2 variant study also only identified 11 DAM genes enriched in AD patients compared with controls. Del Aguila et al., analysing single nucleus transcriptomics from $3 \mathrm{AD}$ patients, were unable to recapitulate an activation signature (DelAguila et al., 2019). This has led to speculation that there is no such DAM signature in humans.

Here we compared the performance of snRNA-Seq to scRNA-Seq for the analysis of microglia from human cortical biopsies, and demonstrated that technical limitations inherent to snRNA-Seq provide a more likely explanation for this lack of consistency in snRNA-Seq studies of AD. We confirmed our results using publicly-available data.

\section{$\underline{\text { Results }}$}

snRNA-Seq recovers major cell types from human tissue, but not microglial state

scRNA-Seq of FACS-sorted microglia was performed on temporal cortices of four human subjects who had undergone neocortical resection (see Supplementary Table 1 for subject data)(Mancuso et al., 2019). We generated snRNA-Seq libraries from these same subjects. Following quality filtering, PCA analysis and clustering of 37,060 nuclei, we identified 7 major cell types (Supplementary Fig. 1a, b): oligodendrocytes (ODC, 34.0\%), excitatory neurons $(27.0 \%)$, interneurons (11.2\%), oligodendrocyte precursors (OPC 9,4\%), microglia $(11.3 \%)$, astrocytes $(6.0 \%)$, and endothelial cells $(1.1 \%)$. We focus here on the microglial population, which was extracted from the main dataset. 
92 We first checked whether clustering analysis of single nuclei could recover subpopulations of microglia comparable to the single cell approach. A comparison of single nucleus and single cell clustering suggested that we could only partially recover similar microglial subcluster structure using both methods (see Supplementary Text and Supplementary Fig. 1c-e).

\section{Gene expression profiling of human nuclei and cells}

To compare gene abundance in single microglial cells (14,823 cells) and nuclei $(3,940$ nuclei), we performed a differential abundance analysis between cells and nuclei from the 4 subjects (Fig. 1a). As demonstrated in previous studies (Bakken et al., 2018; Gerrits et al., 2019; Habib et al., 2017; Lake et al., 2017), the majority of genes showed similar normalized abundance levels in cells and nuclei, with $98.6 \%$ of genes falling along the diagonal in Fig. 1a (Pearson's correlation coefficient $=0.92, \mathrm{p}<2.2 \mathrm{e}-16$ ). However, we identified a group of 246 genes $\left(1.1 \%\right.$ of detected genes) that was less abundant in nuclei (fold change $<-2, p_{\text {adj }}<$ 0.05, blue in Fig. 1a). A second population of 68 genes $(0.3 \%)$ was found to be more abundant in nuclei (fold change $>2$, $p_{\text {adj }}<0.05$, red in Fig. 1a). Additionally, 3,248 genes were exclusively detected in cells, and 5,068 genes exclusively detected in nuclei.

110 The observed differences in abundance between cells and nuclei were consistent across all

111 four subjects (Fig. 1b, Supplementary Fig. 2a). Downsampling of cellular reads indicated

112 that differences in abundance were not the result of different sequencing depths

113 (Supplementary Fig. 2b,c). The full differential abundance results can be found in

114 Supplementary Table 2.

116 To assess the robustness of this finding, we used our nuclei-abundant genes and cell-

117 abundant genes to compare enrichment across all pairs of 8 publicly-available single cell or 118 single nucleus datasets (Supplementary Table 3, Fig. 1c). We consistently found our nuclei-

119 depleted (cell-abundant) genes to be depleted in other single nucleus microglia compared to 120 single cell microglia (mean microglial Z-score of cell-abundant genes was 7.95 when

121 comparing cells to nuclei, whereas cell-to-cell comparisons yielded a mean of 0.01 , and 122 nuclei-to-nuclei comparisons yielded a mean of 0.81 , for $\mathrm{Z}$-scores with $\mathrm{p}_{\text {adj }}<0.05$ ). We also 
123 found our nuclei-abundant genes to be consistently enriched in other microglial nuclei

124 compared with microglial cells (mean microglial Z-score -2.99 compared to -2.33 in nuclei 125 against nuclei, no significant enrichment was found in cell-to-cell comparisons with $p_{\text {adj }}<$

$1260.05)$.

127

128 To assess functional enrichment among genes found to be more abundant in cells or nuclei,

129 we ranked all genes according to log fold change (genes with a low abundance in nuclei had a

130 negative log fold change) and performed a Gene Set Enrichment Analysis (GSEA,

131 Subramanian et al., 2005) against gene markers from previous studies (Fig. 2a). For these

132 analyses, a positive Normalised Enrichment Score (NES) represented nuclear enrichment,

133 and a negative NES represented nuclear depletion. As expected, cytoplasmic RNA (defined

134 by Bahar Halpern et al., 2015) was clearly enriched among genes found to be more abundant

135 in cells $\left(\mathrm{NES}=-1.98, \mathrm{p}_{\text {adj }}=3.6 \mathrm{e}-05\right)$, as was mitochondrial mRNA (NES $=-1.71$, $\mathrm{p}_{\text {adj }}=1.6 \mathrm{e}-$

136 04, gene set extracted from Ensembl's BioMart (Zerbino et al., 2018)). mRNA found to be

137 more abundant in the nucleus by (Bahar Halpern et al., 2015) tended towards enrichment in

138 nuclei but was not significant (NES $\left.=0.87, \mathrm{p}_{\mathrm{adj}}=8.2 \mathrm{e}-01\right)$, which is to be expected as

139 scRNA-Seq captures both nuclear and cytoplasmic RNA. RNA of genes coding for ribosomal

140 proteins were also depleted in nuclei $\left(\mathrm{NES}=-2.28, \mathrm{p}_{\mathrm{adj}}=3.6 \mathrm{e}-05\right)$, as previously described ${ }^{1}$.

141 Genes with shorter coding sequences (CDS) were depleted in nuclei (NES $=-1.38$, $\mathrm{p}_{\text {adj }}=$

142 2.5e-02), while longer CDS were enriched (NES $\left.=2.07, \mathrm{p}_{\mathrm{adj}}=2.1 \mathrm{e}-05\right)$, as already observed

143 in earlier snRNA-Seq studies ${ }^{3}$. Finally, the genes defined by Gerrits (Gerrits et al., 2019) as

144 cellular-enriched in a differential analysis of microglial cells versus (fresh) nuclei in humans

145 were also enriched in cells in our data, showing a NES score of $-2.15\left(p_{\text {adj }}=3.6 e-05\right)$.

147 To further characterise genes with higher or lower abundance in nuclei compared with cells,

148 we performed GSEA, using Gene Ontology (GO) terms extracted from MSigDb (Liberzon et

149 al., 2011) against the ranked log fold change. We selected the 100 terms with the highest

150 NES, and the 100 terms with the lowest NES ( $\left.p_{\text {adj }}<0.05\right)$. Given the high overlap in terms,

151 we clustered ontology terms based on the number of shared genes, in order to define "super"

152 GO clusters (Supplementary Fig. 2e,f). We repeated the GSEA analysis using these super-

153 GO clusters (Fig. 2b, Supplementary Tables 4 and 5) and observed an enrichment of neuronal

154 and synaptic terms in nuclei-abundant genes (also shown in the red population in Fig.1a). We 
suspect a synaptosome contamination during centrifugation. This is supported by the enrichment of synaptosome genes (NES = 1.82, padj =3.6e-05, Fig. 2a; Hafner et al., 2019) and ambient RNA - mRNA originating not from cells/nuclei but from free-floating transcripts in the solution (Macosko et al., 2015) - (NES = 1.71, $\mathrm{p}_{\mathrm{adj}}=9.2 \mathrm{e}-05$, Fig. 2a, Supplementary Fig. 2d) within the nucleus-abundant genes. The two gene sets share a strong overlap (Supplementary Table 6). These genes, although enriched in nuclei compared with cellular levels, still show low abundance (most of these genes show a normalised abundance of no more than 2 - Fig. 1a).

\section{Activation genes identified in mouse models of AD are depleted in human nuclei}

More interesting was the depletion of immune-related genes in nuclei (Fig. 2b). We therefore tested whether microglial activation genes ${ }^{7,8,17}$ were also depleted in nuclei (Fig. 2c,

Supplementary Tables 5 and 6). Remarkably, we found a strong depletion of genes associated with mouse microglial activation: 45 of 257 orthologous DAM genes (Keren-Shaul et al., 2017), $\left(\mathrm{NES}=-2.16, \mathrm{p}_{\text {adj }}=3.6 \mathrm{e}-05\right.$, Fig. $\left.2 \mathrm{c}, \mathrm{d}\right)$, and 28 of 200 orthologous ARM genes (Sala Frigerio et al., 2019) (NES $=-2.01, p_{a d j}=3.6 e-05$, Fig. 2c,e), confirming that mouse microglial activation genes wereless abundant in nuclei. Genes upregulated by LPS stimulation in mice (Gerrits et al., 2019) also showed depletion in nuclei (NES = -1.86, padj $=$ 3.6e-05, Fig. 2c, Supplementary Figure 2g).

\section{Activation genes identified in mouse studies of $A D$ are depleted in human nuclei}

We next examined genes that were identified as markers of the human microglial response to $\mathrm{AD}$ in the recent snRNA-Seq study by (Mathys et al., 2019) (Fig. 2c, f, g). Markers of this response (referred to by Mathys et al. as "Mic1") had a NES score of -2.14 ( $\left.\mathrm{p}_{\text {adj }}=3.6 \mathrm{e}-05\right)$, indicating that they were depleted in nuclei (Fig. 2c). The study identified 28 DAM genes as marker genes of the Mic1 response cluster (shown in orange in Fig. 2f); however the majority of DAM genes were not recovered using their snRNA-Seq protocol (purple in Fig. 2f). Fig.

$1842 \mathrm{~g}$ shows in green all the markers of the human activation cluster Mic1. Clearly, DAM genes and other Mic1 markers showed higher abundance in cells relative to nuclei (confirming the 
186 NES score in Fig. 2c). Further, it seems likely that the recovered DAM genes (orange in Fig.

187 2f) and Mic1 markers in general (green in Fig. 2g), were detected in the original snRNA-Seq

188 experiment owing to their higher nuclear abundance compared with the nuclear abundance of

189 other genes, including those DAM genes that were not recovered (purple in Fig. 2f).

191 Discussion

193 In summary, in our comparison of snRNA-Seq and scRNA-Seq of human microglia, we

194 identified a set of genes (1.1\% of the gene population) with at least 2-fold lower abundance in nuclei compared to their cellular levels (Fig. 1a-b). This small set is strongly enriched for genes previously associated with microglial activation in mouse models of $\mathrm{AD}$, for example $A P O E, C S T 3, F T L, S P P 1$, and CD74 (Fig. 2b-e). Thus, while our work agrees with previous experiments demonstrating that snRNA-Seq can determine cell type (Supplementary Fig. 1a,b), we argue that there are important limitations when studying cellular state in humans. This limitation is likely responsible for the difficulty in identifying consistent DAM- or ARM-like gene populations in the human brain in snRNA-Seq-based studies. We identified similar patterns of depletion in other single nucleus microglia (Fig. 2c).

204 Examination of data from the Mathys et al. study of human nuclei in AD (Mathys et al., 205 2019) shows that only genes with higher nuclear abundance levels were detected (Fig. 2f, g).

206 This suggests that the discordance between human and mouse microglial activation is at least

207 in part a consequence of limitations in the technology, rather than biological differences

208 between the species as current snRNA-Seq suggest. Deeper sequencing (or increased sample 209 sizes) may compensate for this lack of sensitivity. However, the sparse nature of snRNA-Seq 210 and the high level of heterogeneity in human samples, combined with the fact that many 211 relevant genes have a more than two-fold lower abundance in nuclei (e.g. APOE fold change $212=2.57$, CST3 fold change $=3.44, F T L$ fold change $=6.53)$, strongly suggests that this will 213 remain a problem.

215 While our data is (at least partially) in agreement (Fig. 2a, c) with Gerrits et al. (Gerrits et al., 216 2019) which also compares nuclei with cells in human microglia, they did not report a 
217 nuclear depletion of activation genes. We suspect the reason for this is (a) the low human

218 sample number ( $\mathrm{n}=2)$; (b) for the cluster analysis, Gerrits et al. scaled cell and nuclei

219 expression to mitochondrial and ribosomal reads, essentially masking differences between

220 nuclei and cells, and (c) for the differential expression analysis, Gerrits et al. compared fresh

221 cells to fresh nuclei, as opposed to frozen nuclei.

222

223 Alternative approaches may be more suitable for generating a brain atlas of human disease

224 such as AD, particularly where we are limited to frozen material. In situ spatial

225 transcriptomics (ST) negates issues related to tissue dissociation and cell or nucleus isolation

226 (Ståhl et al., 2016), while at the same time retaining spatial information. This approach has

227 recently been applied to examine transcriptomic changes and identify genes that are co-

228 expressed across multiple cell types in the amyloid plaque niche of the mouse brain (Chen et

229 al., 2019). In humans, a similar methodology was recently applied to identify pathway

230 dysregulation and regional differences in cellular states of the postmortem spinal tissue of

231 Amyotrophic Lateral Sclerosis (ALS) patients states (Maniatis et al., 2019). Its application to

232 AD patients may shed light on transcriptomic changes occurring in microglia which localize

233 near plaques, and may also provide insights into the crosstalk occurring between

234 neighbouring cells.

235

236 In conclusion, while snRNA-Seq offers a viable alternative to scRNA-Seq for identification

237 of cell types in tissue where cell dissociation is problematic, its utility for detecting cellular

238 states in disease is limited.

\section{$240 \quad$ Data Availability}

242 Sequencing data from single microglial cells is available on GEO (accession number

243 GSE137444). Sequencing data from single nuclei will be made available on GEO.

\section{Code Availability}


247 Analysis of previous datasets was performed using the EWCE package (Skene and Grant,

248 2016) for $\mathrm{R}$ and the MicroglialDepletion package

249 (https://github.com/NathanSkene/MicroglialDepletion).

250

251

\section{$\underline{\text { Acknowledgements }}$}

252

253 Work in the De Strooper laboratory was supported by the European Union (ERC- 834682 -

254 CELLPHASE_AD), the Fonds voor Wetenschappelijk Onderzoek (FWO), KU Leuven,

255 VIB, UK-DRI (Medical Research council, ARUK and Alzheimer Society), a Methusalem

256 grant from KU Leuven and the Flemish Government, the "Geneeskundige Stichting Koningin

257 Elisabeth", Opening the Future campaign of the Leuven Universitair Fonds (LUF), the

258 Belgian Alzheimer Research Foundation (SAO-FRA) and the Alzheimer's Association USA.

259 Bart De Strooper is holder of the Bax-Vanluffelen Chair for Alzheimer's Disease. Cell

260 sorting was performed at the KU Leuven FACS core facility, and sequencing was carried out

261 by the VIB Nucleomics Core. Renzo Mancuso is recipient of a postdoctoral fellowship from

262 the Alzheimer's Association, USA. Paul M. Matthews acknowledges generous support from

263 the Edmond J. Safra Foundation and Lily Safra, the NIHR Biomedical Research Centre at

264 Imperial College and the UK Dementia Research Institute.

\section{$\underline{\text { Author contributions }}$}

268 Conceptualization: B.D.S., M.F., C.S.F., R.M. ; surgery and extraction of patient tissue samples: T.T. ; Investigation: R.M., L.W., S.P. ; formal analysis: N.T., Y.F., M.F., N.G.S., P.M.M. ; Writing - original draft: N.T., C.S.F., M.F. ; writing - review \& editing: B.D.S., R.M., N.G.S., P.M.M. ; supervision: M.F., B.D.S.

\section{Competing interests}

The authors declare that there are no competing interests. 
Isolation of human primary microglial cells

280 Human primary microglial cells from the Mancuso et. al study (Mancuso et al., 2019) were

281 used. Briefly, microglia were FAC-sorted from brain tissue samples resected from the lateral

282 temporal neocortex of 4 epilepsy patients during neurosurgery. The full protocol is described

283 in the original study. All procedures followed protocols approved by the local Ethical

284 Committee (protocol number S61186). Sequencing was performed as described for the nuclei.

\section{Isolation of nuclei from human subjects}

287 Nuclei from frozen biopsy tissue were isolated as follows: brain tissue was sliced on dry ice, 288 then homogenized manually (15 gentle strokes) with $1 \mathrm{~mL}$ ice-cold Homogenisation Buffer 289 (HB) with $5 \mu \mathrm{L}$ Rnasin Plus. The homogenate was strained with a $70 \mu \mathrm{m}$ strainer and washed 290 with $1.65 \mathrm{~mL}$ to a final volume of $2.65 \mathrm{~mL}$. $2.65 \mathrm{~mL}$ of Gradient medium was added $(\mathrm{Vf}=$ $2915.3 \mathrm{~mL}$ ). To isolate the nuclei, the sample was added to a $4 \mathrm{~mL} 29 \%$ cushion using a P1000, 292 and the weight adjusted with HB. The sample was centrifuged in a SW41Ti rotor at 7,700

$293 \mathrm{rpm}$ for 30 minutes at $4^{\circ} \mathrm{C}$. The supernatant was removed with a plastic Pasteur pipette, 294 followed by removal of the lower supernatant with P200. Nuclei were resuspended in $200 \mu \mathrm{L}$ of resuspension buffer, transferred to a new tube, washed again with $100-200 \mu \mathrm{L}$ resuspension buffer, and pooled with the previous solution. Clumps were disrupted by pipetting with P200, then filtered through a Falcon tube with $0.35 \mu \mathrm{m}$ strainer. $9 \mu \mathrm{L}$ of sample was mixed with $1 \mu \mathrm{L}$ of propidium iodide (PI) stain, loaded onto a LUNA-FL slide and allowed to settle for 30 seconds. We viewed nuclei with the LUNA-FL Automated cell counter to check numbers and shape.

\section{Single nucleus sequencing}

303 RNA sequencing was performed using the 10X Genomics Single Cell 3` Reagent Kit (v2) according to manufacturer protocols. cDNA libraries from fresh-frozen nuclei were sequenced on an Illumina HiSeq platform 4000. Supplementary Table 1 provides sequencing information per sample (for cells and nuclei). 
Alignment. Cellranger v2.1.1 was used to demultiplex and align sequencing output to a human reference genome (assembly hg38 build 95). We used a "pre-mRNA" database to align single nuclei to exons as well as introns (10x Genomics, n.d.). Following alignment, nuclei from one patient sample (RM101.1) were removed due to poor quality (low read and gene count). See Supplementary Table 1 for sample information. Unfiltered count matrices were used for downstream analysis.

Extraction of microglial nuclei. Data was processed using the Seurat v3.0.2 package (Butler et al., 2018; Stuart et al., 2019) in R v3.6.1. For each patient, the count matrix was filtered to exclude nuclei with fewer than 100 genes. Counts were depth-normalised, scaled by 10,000 and log-transformed. FindVariableFeatures was run using a variance-stabilising transformation ("vst") to identify the 2,000 most variable genes in each sample. Data from the 4 patients was then integrated using Seurat's FindIntegrationAnchors with default parameters, and IntegrateData using 40 principal components (PCs). The dataset consisted of 37,060 nuclei, with a mean read depth of 4,305 counts per nucleus, and 1,791 genes per nucleus. Integrated data was scaled (default Seurat parameters). We ran a Principal Components Analysis (PCA), then calculated Uniform Manifold Approximation and Projection (UMAP) embeddings using 40 PCs. We identified clusters using Seurat's FindNeighbours and FindClusters functions, again using 40 PCs. Based on abundance of known celltype markers, we assigned each cluster to a cell type. Microglial clusters were identified using known markers including P2RY12, CSF1R, CX3CR1, and extracted for downstream analysis.

Pre-processing of microglial nuclei per patient. Microglia from each patient sample were analysed individually as described for all cell types above, with the following modifications: raw counts were filtered to remove genes and counts that were \pm 3 standard deviations away from the median value. After normalization, doublets were identified using DoubletFinder v2.0.2 (McGinnis et al., 2019) using 40 PCs, assuming a 7.5\% doublet rate. Following removal of doublets, filtering and Seurat normalization were performed again. Data from patients was then integrated and clusters were identified as above. We discarded small clusters than contained markers for microglia as well as other cell types. After preprocessing, 3,927 nuclei remained, with a mean count depth of 1,295 and a mean gene count of 879 genes per nucleus. 


\section{Single cell analysis}

342 Full details of single cell processing are available in Mancuso et al.(Mancuso et al., 2019).

343 Only cells from the four patients included in the single nucleus study were used here.

\section{Comparisons of single cells and single nuclei}

346 Cluster analysis (see supplementary text). In order to identify microglial cell states in the

347 nuclei data we calculated gene markers for each cluster using Seurat's FindMarkers function,

348 selecting only markers with a positive fold change. Gene markers for cell clusters were

349 extracted from the original Mancuso et al. study. Markers for nuclei and cells are available in

350 Supplementary Table 7. For the analysis, we kept the top 40 significant markers $\left(\mathrm{p}_{\text {adj }}<0.05\right)$

351 based on log fold change for the nuclear clusters and cellular clusters. For each nucleus, we

352 calculated the mean abundance levels of each cell cluster marker set against the aggregated

353 abundance of random control gene sets, using Seurat's AddModuleScore function. This gave

354 us the MS40 score for each marker set. We performed two-sided Fisher's Exact tests with

355 Benjamini Hochberg corrections to determine the overlap of cell cluster markers with nuclear

356 cluster markers (selecting the top 40 markers for each set), using the union of all genes in the

357 cell and nuclei datasets as a background ( $p_{a d j}<0.05$ was considered significant).

358 Differential Abundance. We discarded all non-microglial clusters (brain macrophages,

359 neutrophils), leaving 3,721 nuclei and 14,435 cells. Differential abundance analysis was

360 performed with the Seurat package, using a two-sided Wilcoxon rank sum test, with a

361 Bonferroni correction for multiple testing. Genes with $p_{a d j}<0.05$ and fold change $>|2|$ were

362 considered significant. As Seurat applies a pseudocount of +1 to data before calculating log

363 fold changes, a fold change of 2 corresponds to a log fold change of 0.63 . Log fold changes

364 calculated by Seurat were used for further analysis in gene set enrichment analysis.

365 Scatter plots. We calculated the mean of the normalized abundance levels for cells and for nuclei, and log-transformed these values.

Assessment of nuclear-enriched or cell-enriched gene sets in public scRNA-Seq and SnRNA-

368 Seq datasets. We followed the methodology described in (Skene et al., 2018): genes that were significantly more abundant in nuclei or more abundant in cells (see "Differential abundance" methodology above) were used, creating two gene sets. 8 public datasets were reduced to contain six major cell types: pyramidal neurons, interneurons, astrocytes, interneurons, microglia and oligodendrocyte precursors. Within each dataset, for each gene in our gene sets, 
we calculated a celltype specificity score using the EWCE R package (Github version committed July 29, 2019; Skene and Grant, 2016). For each pair of datasets, $X$ and $Y$, we subtracted the mean microglial specificity score of $Y$ from $X$. We then calculated the same scores for 10,000 random gene sets: the probability and z-score for the difference in specificity for the dendritic genes is calculated using these. Finally, the depletion z-score for each gene set was equal to: (mean subtracted microglial specificity score - bootstrapped mean) / (bootstrapped standard deviation). A large positive z-score thus indicated that the gene set was depleted in microglia of dataset $Y$ relative to dataset $X$. Benjamini-Hochberg multiple testing corrections were applied.

Public datasets. For the Karolinska Institutet (KI) dataset (Skene et al., 2018), we used S1 pyramidal neurons. For the Zeisel 2018 dataset (Zeisel et al., 2018) we used all ACTE* cells as astrocytes, TEGLU* as pyramidal neurons, TEINH* as interneurons, OPC as oligodendrocyte precursors and MGL* as microglia. For the Saunders dataset (Saunders et al., 2018), we used all Neuron.Slc17a7 celltypes from the frontal cortex (FC), hippocampus (HC) or posterior cortex (PC) as pyramidal neurons; all Neuron.Gad1Gad2 cell types from Microglia as microglia. The Lake datasets both came from a single publication (Lake et al., 2018) which had data from frontal cortex, visual cortex and cerebellum. The cerebellum data was not used here. Data from frontal and visual cortices were analyzed separately. All other datasets - Dronc Human (Habib et al., 2017), Dronc Mouse (Habib et al., 2017), Allen Institute for Brain Science (AIBS) (Hodge et al., 2019), Tasic (Tasic et al., 2016) and Habib (Habib et al., 2016) - were used as described previously (Skene et al., 2018). Supplementary Table 3 lists all datasets. An R package is available for the analysis at

397 Functional analysis. We performed Gene Set Enrichment Analysis (GSEA) using the R 398 package fgsea v1.8.0 (Sergushichev, 2016), using default parameters. Gene sets were mapped against a list of genes ranked according to fold change between cellular abundance and nuclear abundance. Gene ontology (GO) sets were obtained from MSigDB (Liberzon et al., 2011; Subramanian et al., 2005). Other gene sets were obtained from previous studies (see significant. 
406

407

408

409

410

411

412

413

414

415

416

417

418

419

420

421

422

423

424

425

426

427

428

429

430

431

432

433

434

435

436

according to normalized enrichment score (with $p_{\text {adj }}<0.05$ ) were clustered as follows: a Jaccard index (the size of the intersection of the two datasets, divided by the size of the union of the two datasets, multiplied by 100) of the overlapping genes was calculated between each significant GO set. The resulting similarity matrix was converted to a dissimilarity matrix, and hierarchical clustering was performed on the matrix. We selected a k value of 16 to group the GO terms based on the hierarchical clustering (see Supplementary Table 2). Gene sets were merged, and each new "super" GO was assigned an annotation manually. GSEA analysis was performed on these super-GO gene sets as described above.

Gene sets from previous studies. We extracted gene sets from previous studies for this analysis. A full list of gene sets is available in Supplementary Table 6. Where data was selected from mouse datasets, we converted the mouse gene to its human ortholog using R's BioMaRt package v2.40.5 (Durinck et al., 2009), selecting only orthologs that displayed 1-to1 orthology. For the ARM gene set we selected the top 200 ARM genes based on log fold change (Sala Frigerio et al., 2019). For the Gerrits human gene set, we took the union of all genes that showed significant differential abundance between cells and nuclei (microglia) from donor 1 and donor 2 (Gerrits et al., 2019). For the LPS gene set, we took the union of all genes significantly upregulated in LPS in cells and in nuclei (microglia) from the Gerrits study (Gerrits et al., 2019).

Downsampling of cell counts. To match cell sequencing depth to nucleus sequencing depth (see Supplementary Fig. 2b,c), we sampled without replacement the number of reads in the cells by a proportion of 0.32 , using the downsampleMatrix function of the DropletUtils $\mathrm{R}$ package v1.4.3 (Griffiths et al., 2018; Lun et al., 2019). This resulted in a read depth of 1,304 compared with the original read depth of 3,979 reads per cell.

Definition of ambient RNA profile in nuclei. We extracted nuclei with less than 700 counts from the original unfiltered raw count matrix of all cell types (resulting in 2,414 nuclei with a mean read depth of 590), and summed the gene counts, under the assumption that these were empty drops rather than nuclei. We took the top 150 genes to represent the ambient RNA profile. The mean read depth of these genes in the empty drops was 121 reads per cell.

\section{$\underline{\text { References }}$}


10x Genomics, n.d. Creating a Reference Package with cellranger mkref -Software -Single Cell Gene Expression -Official 10x Genomics Support [WWW Document]. URL https://support.10xgenomics.com/single-cell-geneexpression/software/pipelines/latest/advanced/references\#premrna (accessed 11.13.19).

Bahar Halpern, K., Caspi, I., Lemze, D., Levy, M., Landen, S., Elinav, E., Ulitsky, I., Itzkovitz, S., 2015. Nuclear Retention of mRNA in Mammalian Tissues. Cell Rep. 13, 2653-2662. https://doi.org/10.1016/j.celrep.2015.11.036

Bakken, T.E., Hodge, R.D., Miller, J.A., Yao, Z., Nguyen, T.N., Aevermann, B., Barkan, E., Bertagnolli, D., Casper, T., Dee, N., Garren, E., Goldy, J., Graybuck, L.T., Kroll, M., Lasken, R.S., Lathia, K., Parry, S., Rimorin, C., Scheuermann, R.H., Schork, N.J., Shehata, S.I., Tieu, M., Phillips, J.W., Bernard, A., Smith, K.A., Zeng, H., Lein, E.S., Tasic, B., 2018. Single-nucleus and single-cell transcriptomes compared in matched cortical cell types. PLOS ONE 13, e0209648. https://doi.org/10.1371/journal.pone.0209648

Butler, A., Hoffman, P., Smibert, P., Papalexi, E., Satija, R., 2018. Integrating single-cell transcriptomic data across different conditions, technologies, and species. Nat. Biotechnol. 36, 411-420. https://doi.org/10.1038/nbt.4096

Chen, W.-T., Lu, A., Craessaerts, K., Pavie, B., Sala Frigerio, C., Mancuso, R., Qian, X., Lalakova, J., Kühnemund, M., Voytyuk, I., Wolfs, L., Snellinx, A., Munck, S., Jurek, A., Fernandez Navarro, J., Saido, T.C., Lundeberg, J., Fiers, M., De Strooper, B., 2019. Spatial and temporal transcriptomics reveal microglia-astroglia crosstalk in the amyloid- $\beta$ plaque cell niche of Alzheimer's disease (preprint). Neuroscience. https://doi.org/10.1101/719930

Del-Aguila, J.L., Li, Z., Dube, U., Mihindukulasuriya, K.A., Budde, J.P., Fernandez, M.V., Ibanez, L., Bradley, J., Wang, F., Bergmann, K., Davenport, R., Morris, J.C., Holtzman, D.M., Perrin, R.J., Benitez, B.A., Dougherty, J., Cruchaga, C., Harari, O., 2019. A single-nuclei RNA sequencing study of Mendelian and sporadic AD in the human brain. Alzheimers Res. Ther. 11, 71. https://doi.org/10.1186/s13195-019-0524-x

Durinck, S., Spellman, P.T., Birney, E., Huber, W., 2009. Mapping Identifiers for the Integration of Genomic Datasets with the R/Bioconductor package biomaRt. Nat. Protoc. 4, 1184-1191. https://doi.org/10.1038/nprot.2009.97

Efthymiou, A.G., Goate, A.M., 2017. Late onset Alzheimer's disease genetics implicates microglial pathways in disease risk. Mol. Neurodegener. 12, 43. https://doi.org/10.1186/s13024-017-0184-x

Fonseca, M.I., Chu, S.-H., Hernandez, M.X., Fang, M.J., Modarresi, L., Selvan, P., MacGregor, G.R., Tenner, A.J., 2017. Cell-specific deletion of $\mathrm{Clqa}$ identifies microglia as the dominant source of $\mathrm{Clq}$ in mouse brain. J. Neuroinflammation 14, 48. https://doi.org/10.1186/s12974-017-0814-9

Friedman, B.A., Srinivasan, K., Ayalon, G., Meilandt, W.J., Lin, H., Huntley, M.A., Cao, Y., Lee, S.-H., Haddick, P.C.G., Ngu, H., Modrusan, Z., Larson, J.L., Kaminker, J.S., Brug, M.P. van der, Hansen, D.V., 2018. Diverse Brain Myeloid Expression Profiles Reveal Distinct Microglial Activation States and Aspects of Alzheimer's Disease Not Evident in Mouse Models. Cell Rep. 22, 832-847. https://doi.org/10.1016/j.celrep.2017.12.066

Gerrits, E., Heng, Y., Boddeke, E.W.G.M., Eggen, B.J.L., 2019. Transcriptional profiling of microglia; current state of the art and future perspectives. Glia n/a. https://doi.org/10.1002/glia.23767

Griffiths, J.A., Richard, A.C., Bach, K., Lun, A.T.L., Marioni, J.C., 2018. Detection and removal of barcode swapping in single-cell RNA-seq data. Nat. Commun. 9, 1-6. https://doi.org/10.1038/s41467-018-05083-x

Grubman, A., Chew, G., Ouyang, J.F., Sun, G., Choo, X.Y., McLean, C., Simmons, R.K., Buckberry, S., Vargas-Landin, D.B., Poppe, D., Pflueger, J., Lister, R., Rackham, O.J.L., Petretto, E., Polo, J.M., 2019. A single-cell atlas of entorhinal cortex from individuals with Alzheimer's disease reveals cell-type-specific gene expression regulation. Nat. Neurosci. 1-11. https://doi.org/10.1038/s41593-019-0539-4

Habib, N., Avraham-Davidi, I., Basu, A., Burks, T., Shekhar, K., Hofree, M., Choudhury, S.R., Aguet, F., Gelfand, E., Ardlie, K., Weitz, D.A., Rozenblatt-Rosen, O., Zhang, F., Regev, A., 2017. Massively parallel single-nucleus RNA-seq with DroNc-seq. Nat. Methods 14, 955-958. https://doi.org/10.1038/nmeth.4407

Habib, N., Li, Y., Heidenreich, M., Swiech, L., Avraham-Davidi, I., Trombetta, J.J., Hession, C., Zhang, F., Regev, A., 2016. Div-Seq: Single-nucleus RNA-Seq reveals dynamics of rare adult newborn neurons. Science 353, 925-928. https://doi.org/10.1126/science.aad7038 
Hafner, A.-S., Donlin-Asp, P.G., Leitch, B., Herzog, E., Schuman, E.M., 2019. Local protein synthesis is a ubiquitous feature of neuronal pre- and postsynaptic compartments. Science 364. https://doi.org/10.1126/science.aau3644 Hasselmann, J., Coburn, M.A., England, W., Figueroa Velez, D.X., Kiani Shabestari, S., Tu, C.H., McQuade, A., Kolahdouzan, M., Echeverria, K., Claes, C., Nakayama, T., Azevedo, R., Coufal, N.G., Han, C.Z., Cummings, B.J., Davtyan, H., Glass, C.K., Healy, L.M., Gandhi, S.P., Spitale, R.C., Blurton-Jones, M., 2019. Development of a Chimeric Model to Study and Manipulate Human Microglia In Vivo. Neuron. https://doi.org/10.1016/j.neuron.2019.07.002

Hodge, R.D., Bakken, T.E., Miller, J.A., Smith, K.A., Barkan, E.R., Graybuck, L.T., Close, J.L., Long, B., Johansen, N., Penn, O., Yao, Z., Eggermont, J., Höllt, T., Levi, B.P., Shehata, S.I., Aevermann, B., Beller, A., Bertagnolli, D., Brouner, K., Casper, T., Cobbs, C., Dalley, R., Dee, N., Ding, S.-L., Ellenbogen, R.G., Fong, O., Garren, E., Goldy, J., Gwinn, R.P., Hirschstein, D., Keene, C.D., Keshk, M., Ko, A.L., Lathia, K., Mahfouz, A., Maltzer, Z., McGraw, M., Nguyen, T.N., Nyhus, J., Ojemann, J.G., Oldre, A., Parry, S., Reynolds, S., Rimorin, C., Shapovalova, N.V., Somasundaram, S., Szafer, A., Thomsen, E.R., Tieu, M., Quon, G., Scheuermann, R.H., Yuste, R., Sunkin, S.M., Lelieveldt, B., Feng, D., Ng, L., Bernard, A., Hawrylycz, M., Phillips, J.W., Tasic, B., Zeng, H., Jones, A.R., Koch, C., Lein, E.S., 2019. Conserved cell types with divergent features in human versus mouse cortex. Nature 1-8. https://doi.org/10.1038/s41586-019-1506-7

Jansen, I.E., Savage, J.E., Watanabe, K., Bryois, J., Williams, D.M., Steinberg, S., Sealock, J., Karlsson, I.K., Hägg, S., Athanasiu, L., Voyle, N., Proitsi, P., Witoelar, A., Stringer, S., Aarsland, D., Almdahl, I.S., Andersen, F., Bergh, S., Bettella, F., Bjornsson, S., Brækhus, A., Bråthen, G., de Leeuw, C., Desikan, R.S., Djurovic, S., Dumitrescu, L., Fladby, T., Hohman, T.J., Jonsson, P.V., Kiddle, S.J., Rongve, A., Saltvedt, I., Sando, S.B., Selbæk, G., Shoai, M., Skene, N.G., Snaedal, J., Stordal, E., Ulstein, I.D., Wang, Y., White, L.R., Hardy, J., Hjerling-Leffler, J., Sullivan, P.F., van der Flier, W.M., Dobson, R., Davis, L.K., Stefansson, H., Stefansson, K., Pedersen, N.L., Ripke, S., Andreassen, O.A., Posthuma, D., 2019. Genome-wide meta-analysis identifies new loci and functional pathways influencing Alzheimer's disease risk. Nat. Genet. https://doi.org/10.1038/s41588-018-0311-9

Keren-Shaul, H., Spinrad, A., Weiner, A., Matcovitch-Natan, O., Dvir-Szternfeld, R., Ulland, T.K., David, E., Baruch, K., Lara-Astaiso, D., Toth, B., Itzkovitz, S., Colonna, M., Schwartz, M., Amit, I., 2017. A Unique Microglia Type Associated with Restricting Development of Alzheimer's Disease. Cell 169, 1276-1290.e17. https://doi.org/10.1016/j.cell.2017.05.018

Krasemann, S., Madore, C., Cialic, R., Baufeld, C., Calcagno, N., Fatimy, R.E., Beckers, L., O’Loughlin, E., Xu, Y., Fanek, Z., Greco, D.J., Smith, S.T., Tweet, G., Humulock, Z., Zrzavy, T., Conde-Sanroman, P., Gacias, M., Weng, Z., Chen, H., Tjon, E., Mazaheri, F., Hartmann, K., Madi, A., Ulrich, J.D., Glatzel, M., Worthmann, A., Heeren, J., Budnik, B., Lemere, C., Ikezu, T., Heppner, F.L., Litvak, V., Holtzman, D.M., Lassmann, H., Weiner, H.L., Ochando, J., Haass, C., Butovsky, O., 2017. The TREM2-APOE Pathway Drives the Transcriptional Phenotype of Dysfunctional Microglia in Neurodegenerative Diseases. Immunity 47, 566-581.e9. https://doi.org/10.1016/j.immuni.2017.08.008

Kunkle, B.W., Grenier-Boley, B., Sims, R., Bis, J.C., Damotte, V., Naj, A.C., Boland, A., Vronskaya, M., Lee, S.J. van der, Amlie-Wolf, A., Bellenguez, C., Frizatti, A., Chouraki, V., Martin, E.R., Sleegers, K., Badarinarayan, N., Jakobsdottir, J., Hamilton-Nelson, K.L., Moreno-Grau, S., Olaso, R., Raybould, R., Chen, Y., Kuzma, A.B., Hiltunen, M., Morgan, T., Ahmad, S., Vardarajan, B.N., Epelbaum, J., Hoffmann, P., Boada, M., Beecham, G.W., Garnier, J.-G., Harold, D., Fitzpatrick, A.L., Valladares, O., Moutet, M.-L., Gerrish, A., Smith, A.V., Qu, L., Bacq, D., Denning, N., Jian, X., Zhao, Y., Zompo, M.D., Fox, N.C., Choi, S.-H., Mateo, I., Hughes, J.T., Adams, H.H., Malamon, J., Sanchez-Garcia, F., Patel, Y., Brody, J.A., Dombroski, B.A., Naranjo, M.C.D., Daniilidou, M., Eiriksdottir, G., Mukherjee, S., Wallon, D., Uphill, J., Aspelund, T., Cantwell, L.B., Garzia, F., Galimberti, D., Hofer, E., Butkiewicz, M., Fin, B., Scarpini, E., Sarnowski, C., Bush, W.S., Meslage, S., Kornhuber, J., White, C.C., Song, Y., Barber, R.C., Engelborghs, S., Sordon, S., Voijnovic, D., Adams, P.M., Vandenberghe, R., 
Mayhaus, M., Cupples, L.A., Albert, M.S., Deyn, P.P.D., Gu, W., Himali, J.J., Beekly, D., Squassina, A., Hartmann, A.M., Orellana, A., Blacker, D., Rodriguez-Rodriguez, E., Lovestone, S., Garcia, M.E., Doody, R.S., Munoz-Fernadez, C., Sussams, R., Lin, H., Fairchild, T.J., Benito, Y.A., Holmes, C., Karamujić-Čomić, H., Frosch, M.P., Thonberg, H., Maier, W., Roschupkin, G., Ghetti, B., Giedraitis, V., Kawalia, A., Li, S., Huebinger, R.M., Kilander, L., Moebus, S., Hernández, I., Kamboh, M.I., Brundin, R., Turton, J., Yang, Q., Katz, M.J., Concari, L., Lord, J., Beiser, A.S., Keene, C.D., Helisalmi, S., Kloszewska, I., Kukull, W.A., Koivisto, A.M., Lynch, A., Tarraga, L., Larson, E.B., Haapasalo, A., Lawlor, B., Mosley, T.H., Lipton, R.B., Solfrizzi, V., Gill, M., Longstreth, W.T., Montine, T.J., Frisardi, V., Diez-Fairen, M., Rivadeneira, F., Petersen, R.C., Deramecourt, V., Alvarez, I., Salani, F., Ciaramella, A., Boerwinkle, E., Reiman, E.M., Fievet, N., Rotter, J.I., Reisch, J.S., Hanon, O., Cupidi, C., Uitterlinden, A.G.A., Royall, D.R., Dufouil, C., Maletta, R.G., Rojas, I. de, Sano, M., Brice, A., Cecchetti, R., George-Hyslop, P.S., Ritchie, K., Tsolaki, M., Tsuang, D.W., Dubois, B., Craig, D., Wu, C.-K., Soininen, H., Avramidou, D., Albin, R.L., Fratiglioni, L., Germanou, A., Apostolova, L.G., Keller, L., Koutroumani, M., Arnold, S.E., Panza, F., Gkatzima, O., Asthana, S., Hannequin, D., Whitehead, P., Atwood, C.S., Caffarra, P., Hampel, H., Quintela, I., Carracedo, Á., Lannfelt, L., Rubinsztein, D.C., Barnes, L.L., Pasquier, F., Frölich, L., Barral, S., McGuinness, B., Beach, T.G., Johnston, J.A., Becker, J.T., Passmore, P., Bigio, E.H., Schott, J.M., Bird, T.D., Warren, J.D., Boeve, B.F., Lupton, M.K., Bowen, J.D., Proitsi, P., Boxer, A., Powell, J.F., Burke, J.R., Kauwe, J.S.K., Burns, J.M., Mancuso, M., Buxbaum, J.D., Bonuccelli, U., Cairns, N.J., McQuillin, A., Cao, C., Livingston, G., Carlson, C.S., Bass, N.J., Carlsson, C.M., Hardy, J., Carney, R.M., Bras, J., Carrasquillo, M.M., Guerreiro, R., Allen, M., Chui, H.C., Fisher, E., Masullo, C., Crocco, E.A., DeCarli, C., Bisceglio, G., Dick, M., Ma, L., Duara, R., Graff-Radford, N.R., Evans, D.A., Hodges, A., Faber, K.M., Scherer, M., Fallon, K.B., Riemenschneider, M., Fardo, D.W., Heun, R., Farlow, M.R., Kölsch, H., Ferris, S., Leber, M., Foroud, T.M., Heuser, I., Galasko, D.R., Giegling, I., Gearing, M., Hüll, M., Geschwind, D.H., Gilbert, J.R., Morris, J., Green, R.C., Mayo, K., Growdon, J.H., Feulner, T., Hamilton, R.L., Harrell, L.E., Drichel, D., Honig, L.S., Cushion, T.D., Huentelman, M.J., Hollingworth, P., Hulette, C.M., Hyman, B.T., Marshall, R., Jarvik, G.P., Meggy, A., Abner, E., Menzies, G.E., Jin, L.-W., Leonenko, G., Real, L.M., Jun, G.R., Baldwin, C.T., Grozeva, D., Karydas, A., Russo, G., Kaye, J.A., Kim, R., Jessen, F., Kowall, N.W., Vellas, B., Kramer, J.H., Vardy, E., LaFerla, F.M., Jöckel, K.-H., Lah, J.J., Dichgans, M., Leverenz, J.B., Mann, D., Levey, A.I., Pickering-Brown, S., Lieberman, A.P., Klopp, N., Lunetta, K.L., Wichmann, H.-E., Lyketsos, C.G., Morgan, K., Marson, D.C., Brown, K., Martiniuk, F., Medway, C., Mash, D.C., Nöthen, M.M., Masliah, E., Hooper, N.M., McCormick, W.C., Daniele, A., McCurry, S.M., Bayer, A., McDavid, A.N., Gallacher, J., McKee, A.C., Bussche, H. van den, Mesulam, M., Brayne, C., Miller, B.L., Riedel-Heller, S., Miller, C.A., Miller, J.W., Al-Chalabi, A., Morris, J.C., Shaw, C.E., Myers, A.J., Wiltfang, J., O’Bryant, S., Olichney, J.M., Alvarez, V., Parisi, J.E., Singleton, A.B., Paulson, H.L., Collinge, J., Perry, W.R., Mead, S., Peskind, E., Cribbs, D.H., Rossor, M., Pierce, A., Ryan, N.S., Poon, W.W., Nacmias, B., Potter, H., Sorbi, S., Quinn, J.F., Sacchinelli, E., Raj, A., Spalletta, G., Raskind, M., Caltagirone, C., Bossù, P., Orfei, M.D., Reisberg, B., Clarke, R., Reitz, C., Smith, A.D., Ringman, J.M., Warden, D., Roberson, E.D., Wilcock, G., Rogaeva, E., Bruni, A.C., Rosen, H.J., Gallo, M., Rosenberg, R.N., Ben-Shlomo, Y., Sager, M.A., Mecocci, P., Saykin, A.J., Pastor, P., Cuccaro, M.L., Vance, J.M., Schneider, J.A., Schneider, L.S., Slifer, S., Seeley, W.W., Smith, A.G., Sonnen, J.A., Spina, S., Stern, R.A., Swerdlow, R.H., Tang, M., Tanzi, R.E., Trojanowski, J.Q., Troncoso, J.C., Deerlin, V.M.V., Eldik, L.J.V., Vinters, H.V., Vonsattel, J.P., Weintraub, S., Welsh-Bohmer, K.A., Wilhelmsen, K.C., Williamson, J., Wingo, T.S., Woltjer, R.L., Wright, C.B., Yu, C.-E., Yu, L., Saba, Y., Pilotto, A., Bullido, M.J., Peters, O., Crane, P.K., Bennett, D., Bosco, P., Coto, E., Boccardi, V., Jager, P.L.D., Lleo, A., Warner, N., Lopez, O.L., Ingelsson, M., Deloukas, P., Cruchaga, C., Graff, C., Gwilliam, R., Fornage, M., Goate, A.M., Sanchez-Juan, P., Kehoe, P.G., Amin, N., Ertekin-Taner, N., Berr, C., Debette, S., Love, S., Launer, L.J., Younkin, S.G., Dartigues, J.-F., Corcoran, C., Ikram, M.A., Dickson, D.W., Nicolas, G., Campion, D., Tschanz, J., Schmidt, H., Hakonarson, H., Clarimon, J., Munger, R., Schmidt, R., Farrer, L.A., 
Broeckhoven, C.V., O’Donovan, M.C., DeStefano, A.L., Jones, L., Haines, J.L., Deleuze, J.-F., Owen, M.J., Gudnason, V., Mayeux, R., Escott-Price, V., Psaty, B.M., Ramirez, A., Wang, L.-S., Ruiz, A., Duijn, C.M. van, Holmans, P.A., Seshadri, S., Williams, J., Amouyel, P., Schellenberg, G.D., Lambert, J.-C., Pericak-Vance, M.A., 2019. Genetic meta-analysis of diagnosed Alzheimer's disease identifies new risk loci and implicates $A \beta$, tau, immunity and lipid processing. Nat. Genet. 51, 414 430. https://doi.org/10.1038/s41588-019-0358-2

Lake, B.B., Ai, R., Kaeser, G.E., Salathia, N.S., Yung, Y.C., Liu, R., Wildberg, A., Gao, D., Fung, H.-L., Chen, S., Vijayaraghavan, R., Wong, J., Chen, A., Sheng, X., Kaper, F., Shen, R., Ronaghi, M., Fan, J.-B., Wang, W., Chun, J., Zhang, K., 2016. Neuronal subtypes and diversity revealed by single-nucleus RNA sequencing of the human brain. Science 352, 1586-1590. https://doi.org/10.1126/science.aaf1204

Lake, B.B., Chen, S., Sos, B.C., Fan, J., Kaeser, G.E., Yung, Y.C., Duong, T.E., Gao, D., Chun, J., Kharchenko, P.V., Zhang, K., 2018. Integrative single-cell analysis of transcriptional and epigenetic states in the human adult brain. Nat. Biotechnol. 36, 70-80. https://doi.org/10.1038/nbt.4038

Lake, B.B., Codeluppi, S., Yung, Y.C., Gao, D., Chun, J., Kharchenko, P.V., Linnarsson, S., Zhang, K., 2017. A comparative strategy for single-nucleus and single-cell transcriptomes confirms accuracy in predicted cell-type expression from nuclear RNA. Sci. Rep. 7, 6031. https://doi.org/10.1038/s41598-017-04426-w

Lambert, J.C., Ibrahim-Verbaas, C.A., Harold, D., Naj, A.C., Sims, R., Bellenguez, C., DeStafano, A.L., Bis, J.C., Beecham, G.W., Grenier-Boley, B., Russo, G., Thorton-Wells, T.A., Jones, N., Smith, A.V., Chouraki, V., Thomas, C., Ikram, M.A., Zelenika, D., Vardarajan, B.N., Kamatani, Y., Lin, C.F., Gerrish, A., Schmidt, H., Kunkle, B., Dunstan, M.L., Ruiz, A., Bihoreau, M.T., Choi, S.H., Reitz, C., Pasquier, F., Cruchaga, C., Craig, D., Amin, N., Berr, C., Lopez, O.L., De Jager, P.L., Deramecourt, V., Johnston, J.A., Evans, D., Lovestone, S., Letenneur, L., Moron, F.J., Rubinsztein, D.C., Eiriksdottir, G., Sleegers, K., Goate, A.M., Fievet, N., Huentelman, M.W., Gill, M., Brown, K., Kamboh, M.I., Keller, L., Barberger-Gateau, P., McGuiness, B., Larson, E.B., Green, R., Myers, A.J., Dufouil, C., Todd, S., Wallon, D., Love, S., Rogaeva, E., Gallacher, J., St George-Hyslop, P., Clarimon, J., Lleo, A., Bayer, A., Tsuang, D.W., Yu, L., Tsolaki, M., Bossu, P., Spalletta, G., Proitsi, P., Collinge, J., Sorbi, S., Sanchez-Garcia, F., Fox, N.C., Hardy, J., Deniz Naranjo, M.C., Bosco, P., Clarke, R., Brayne, C., Galimberti, D., Mancuso, M., Matthews, F., Moebus, S., Mecocci, P., Del Zompo, M., Maier, W., Hampel, H., Pilotto, A., Bullido, M., Panza, F., Caffarra, P., Nacmias, B., Gilbert, J.R., Mayhaus, M., Lannefelt, L., Hakonarson, H., Pichler, S., Carrasquillo, M.M., Ingelsson, M., Beekly, D., Alvarez, V., Zou, F., Valladares, O., Younkin, S.G., Coto, E., Hamilton-Nelson, K.L., Gu, W., Razquin, C., Pastor, P., Mateo, I., Owen, M.J., Faber, K.M., Jonsson, P.V., Combarros, O., O’Donovan, M.C., Cantwell, L.B., Soininen, H., Blacker, D., Mead, S., Mosley, T.H.J., Bennett, D.A., Harris, T.B., Fratiglioni, L., Holmes, C., de Bruijn, R.F., Passmore, P., Montine, T.J., Bettens, K., Rotter, J.I., Brice, A., Morgan, K., Foroud, T.M., Kukull, W.A., Hannequin, D., Powell, J.F., Nalls, M.A., Ritchie, K., Lunetta, K.L., Kauwe, J.S., Boerwinkle, E., Riemenschneider, M., Boada, M., Hiltuenen, M., Martin, E.R., Schmidt, R., Rujescu, D., Wang, L.S., Dartigues, J.F., Mayeux, R., Tzourio, C., Hofman, A., Nothen, M.M., Graff, C., Psaty, B.M., Jones, L., Haines, J.L., Holmans, P.A., Lathrop, M., Pericak-Vance, M.A., Launer, L.J., Farrer, L.A., van Duijn, C.M., Van Broeckhoven, C., Moskvina, V., Seshadri, S., Williams, J., Schellenberg, G.D., Amouyel, P., 2013. Meta-analysis of 74,046 individuals identifies 11 new susceptibility loci for Alzheimer's disease. Nat. Genet. 45, 1452-1458. https://doi.org/10.1038/ng.2802

Liberzon, A., Subramanian, A., Pinchback, R., Thorvaldsdóttir, H., Tamayo, P., Mesirov, J.P., 2011. Molecular signatures database (MSigDB) 3.0. Bioinformatics 27, 1739-1740. https://doi.org/10.1093/bioinformatics/btr260

Lun, A.T.L., Riesenfeld, S., Andrews, T., Dao, T.P., Gomes, T., Marioni, J.C., participants in the 1st Human Cell Atlas Jamboree, 2019. EmptyDrops: distinguishing cells from empty droplets in droplet-based single-cell RNA sequencing data. Genome Biol. 20, 63. https://doi.org/10.1186/s13059-019-1662-y

Macosko, E.Z., Basu, A., Satija, R., Nemesh, J., Shekhar, K., Goldman, M., Tirosh, I., Bialas, A.R., Kamitaki, N., Martersteck, E.M., Trombetta, J.J., Weitz, D.A., Sanes, J.R., Shalek, A.K., Regev, A., McCarroll, S.A., 2015. 
Mancuso, R., Daele, J.V.D., Fattorelli, N., Wolfs, L., Balusu, S., Burton, O., Liston, A., Sierksma, A., Fourne, Y., Poovathingal, S., Arranz-Mendiguren, A., Frigerio, C.S., Claes, C., Serneels, L., Theys, T., Perry, V.H., Verfaillie, C., Fiers, M., Strooper, B.D., 2019. Stem-cell-derived human microglia transplanted in mouse brain to study human disease. Nat. Neurosci. 1-6. https://doi.org/10.1038/s41593-019-0525-x

Maniatis, S., Äijö, T., Vickovic, S., Braine, C., Kang, K., Mollbrink, A., Fagegaltier, D., Saiz-Castro, G., Cuevas, M., Watters, A., Lundeberg, J., Bonneau, R., Phatnani, H., 2019. Spatiotemporal dynamics of molecular pathology in amyotrophic lateral sclerosis 6.

Marioni, R.E., Harris, S.E., Zhang, Q., McRae, A.F., Hagenaars, S.P., Hill, W.D., Davies, G., Ritchie, C.W., Gale, C.R., Starr, J.M., Goate, A.M., Porteous, D.J., Yang, J., Evans, K.L., Deary, I.J., Wray, N.R., Visscher, P.M., 2018. GWAS on family history of Alzheimer's disease. Transl. Psychiatry 8, 99. https://doi.org/10.1038/s41398-0180150-6

Mathys, H., Davila-Velderrain, J., Peng, Z., Gao, F., Mohammadi, S., Young, J.Z., Menon, M., He, L., Abdurrob, F., Jiang, X., Martorell, A.J., Ransohoff, R.M., Hafler, B.P., Bennett, D.A., Kellis, M., Tsai, L.-H., 2019. Single-cell transcriptomic analysis of Alzheimer's disease. Nature 1. https://doi.org/10.1038/s41586-019-1195-2

McGeer, P.L., Itagaki, S., Tago, H., McGeer, E.G., 1987. Reactive microglia in patients with senile dementia of the Alzheimer type are positive for the histocompatibility glycoprotein HLA-DR. Neurosci. Lett. 79, 195-200. https://doi.org/10.1016/0304-3940(87)90696-3

McGinnis, C.S., Murrow, L.M., Gartner, Z.J., 2019. DoubletFinder: Doublet Detection in Single-Cell RNA Sequencing Data Using Artificial Nearest Neighbors. Cell Syst. 8, 329-337.e4. https://doi.org/10.1016/j.cels.2019.03.003

Sala Frigerio, C., Wolfs, L., Fattorelli, N., Thrupp, N., Voytyuk, I., Schmidt, I., Mancuso, R., Chen, W.-T., Woodbury, M.E., Srivastava, G., Möller, T., Hudry, E., Das, S., Saido, T., Karran, E., Hyman, B., Perry, V.H., Fiers, M., Strooper, B.D., 2019. The Major Risk Factors for Alzheimer's Disease: Age, Sex, and Genes Modulate the Microglia Response to A $\beta$ Plaques. Cell Rep. 27, 1293-1306.e6. https://doi.org/10.1016/j.celrep.2019.03.099

Saunders, A., Macosko, E.Z., Wysoker, A., Goldman, M., Krienen, F.M., de Rivera, H., Bien, E., Baum, M., Bortolin, L., Wang, S., Goeva, A., Nemesh, J., Kamitaki, N., Brumbaugh, S., Kulp, D., McCarroll, S.A., 2018. Molecular Diversity and Specializations among the Cells of the Adult Mouse Brain. Cell 174, 1015-1030.e16. https://doi.org/10.1016/j.cell.2018.07.028

Sergushichev, A.A., 2016. An algorithm for fast preranked gene set enrichment analysis using cumulative statistic calculation. bioRxiv 060012. https://doi.org/10.1101/060012

Skene, N.G., Bryois, J., Bakken, T.E., Breen, G., Crowley, J.J., Gaspar, H.A., Giusti-Rodriguez, P., Hodge, R.D., Miller, J.A., Muñoz-Manchado, A.B., O’Donovan, M.C., Owen, M.J., Pardiñas, A.F., Ryge, J., Walters, J.T.R., Linnarsson, S., Lein, E.S., Sullivan, P.F., Hjerling-Leffler, J., 2018. Genetic identification of brain cell types underlying schizophrenia. Nat. Genet. 50, 825-833. https://doi.org/10.1038/s41588-018-0129-5

Skene, N.G., Grant, S.G.N., 2016. Identification of Vulnerable Cell Types in Major Brain Disorders Using Single Cell Transcriptomes and Expression Weighted Cell Type Enrichment. Front. Neurosci. 10. https://doi.org/10.3389/fnins.2016.00016

Ståhl, P.L., Salmén, F., Vickovic, S., Lundmark, A., Navarro, J.F., Magnusson, J., Giacomello, S., Asp, M., Westholm, J.O., Huss, M., Mollbrink, A., Linnarsson, S., Codeluppi, S., Borg, Å., Pontén, F., Costea, P.I., Sahlén, P., Mulder, J., Bergmann, O., Lundeberg, J., Frisén, J., 2016. Visualization and analysis of gene expression in tissue sections by spatial transcriptomics. Science 353, 78-82. https://doi.org/10.1126/science.aaf2403

Stuart, T., Butler, A., Hoffman, P., Hafemeister, C., Papalexi, E., Mauck, W.M., Hao, Y., Stoeckius, M., Smibert, P., Satija, R., 2019. Comprehensive Integration of Single-Cell Data. Cell 177, 1888-1902.e21. https://doi.org/10.1016/j.cell.2019.05.031 
bioRxiv preprint doi: https://doi.org/10.1101/2020.04.13.035386; this version posted April 13, 2020. The copyright holder for this preprint (which was not certified by peer review) is the author/funder, who has granted bioRxiv a license to display the preprint in perpetuity. It is made available under aCC-BY-NC-ND 4.0 International license.

Subramanian, A., Tamayo, P., Mootha, V.K., Mukherjee, S., Ebert, B.L., Gillette, M.A., Paulovich, A., Pomeroy, S.L., Golub, T.R., Lander, E.S., Mesirov, J.P., 2005. Gene set enrichment analysis: A knowledge-based approach for interpreting genome-wide expression profiles. Proc. Natl. Acad. Sci. U. S. A. 102, 15545-15550. https://doi.org/10.1073/pnas.0506580102

Tasic, B., Menon, V., Nguyen, T.N., Kim, T.K., Jarsky, T., Yao, Z., Levi, B., Gray, L.T., Sorensen, S.A., Dolbeare, T., Bertagnolli, D., Goldy, J., Shapovalova, N., Parry, S., Lee, C., Smith, K., Bernard, A., Madisen, L., Sunkin, S.M., Hawrylycz, M., Koch, C., Zeng, H., 2016. Adult mouse cortical cell taxonomy revealed by single cell transcriptomics. Nat. Neurosci. 19, 335-346. https://doi.org/10.1038/nn.4216

Zeisel, A., Hochgerner, H., Lönnerberg, P., Johnsson, A., Memic, F., van der Zwan, J., Häring, M., Braun, E., Borm, L.E., La Manno, G., Codeluppi, S., Furlan, A., Lee, K., Skene, N., Harris, K.D., Hjerling-Leffler, J., Arenas, E., Ernfors, P., Marklund, U., Linnarsson, S., 2018. Molecular Architecture of the Mouse Nervous System. Cell 174, 9991014.e22. https://doi.org/10.1016/j.cell.2018.06.021

Zerbino, D.R., Achuthan, P., Akanni, W., Amode, M.R., Barrell, D., Bhai, J., Billis, K., Cummins, C., Gall, A., Girón, C.G., Gil, L., Gordon, L., Haggerty, L., Haskell, E., Hourlier, T., Izuogu, O.G., Janacek, S.H., Juettemann, T., To, J.K., Laird, M.R., Lavidas, I., Liu, Z., Loveland, J.E., Maurel, T., McLaren, W., Moore, B., Mudge, J., Murphy, D.N., Newman, V., Nuhn, M., Ogeh, D., Ong, C.K., Parker, A., Patricio, M., Riat, H.S., Schuilenburg, H., Sheppard, D., Sparrow, H., Taylor, K., Thormann, A., Vullo, A., Walts, B., Zadissa, A., Frankish, A., Hunt, S.E., Kostadima, M., Langridge, N., Martin, F.J., Muffato, M., Perry, E., Ruffier, M., Staines, D.M., Trevanion, S.J., Aken, B.L., Cunningham, F., Yates, A., Flicek, P., 2018. Ensembl 2018. Nucleic Acids Res. 46, D754-D761. https://doi.org/10.1093/nar/gkx1098

Zhou, Y., Song, W.M., Andhey, P.S., Swain, A., Levy, T., Miller, K.R., Poliani, P.L., Cominelli, M., Grover, S., Gilfillan, S., Cella, M., Ulland, T.K., Zaitsev, K., Miyashita, A., Ikeuchi, T., Sainouchi, M., Kakita, A., Bennett, D.A., Schneider, J.A., Nichols, M.R., Beausoleil, S.A., Ulrich, J.D., Holtzman, D.M., Artyomov, M.N., Colonna, M., 2020. Human and mouse single-nucleus transcriptomics reveal TREM2-dependent and TREM2-independent cellular responses in Alzheimer's disease. Nat. Med. 26, 131-142. https://doi.org/10.1038/s41591-019-0695-9 


\section{$690 \quad$ Figures}

691

692 Fig. 1: Gene abundance in single microglial cells versus single microglial nuclei of

693 human cortical tissue. a. Mean normalised gene abundance in cells (x axis) and nuclei. (y

694 axis). Red: genes with significantly higher abundance in nuclei ( $p_{\text {adj }}<0.05$, fold change $>2$ ).

695 Blue: genes that are significantly less abundance in nuclei $\left(\mathrm{p}_{\mathrm{adj}}<0.05\right.$, fold change $\left.<-2\right)$.

696 Genes were normalized to read depth (per cell), scaled by 10,000 and log-transformed.

697 MALAT1 (which had normalized abundance levels of 6.0 and 6.9 respectively in cells and

698 nuclei) has been removed for visualisation purposes. $\mathrm{FC}=$ fold change. Full results are

699 available in Supplementary Table 2. b. Scatterplot as in a), per patient (with the same genes

700 highlighted). Supplementary Table 1 contains patient data. c. Each bar represents a

701 comparison between two datasets ( $X$ versus $Y$ ), with the bootstrapped $z$-scores representing

702 the extent to which cell-enriched genes (top panel) and nuclear-enriched genes (bottom panel)

703 have lower specificity for microglia in dataset $Y$ relative to that in dataset $X$. Larger $z$-scores

704 indicate greater depletion of genes, and red bars indicate a statistically significant depletion

705 ( . adj $_{\text {. }}<0.05$, by bootstrapping). KI $=$ Karolinska Institutet $;$ AIBS $=$ Allen Institute for Brain

706 Science. 
bioRxiv preprint doi: https://doi.org/10.1101/2020.04.13.035386; this version posted April 13, 2020. The copyright holder for this preprint

(which was not certified by peer review) is the author/funder, who has granted bioRxiv a license to display the preprint in perpetuity. It is made available under aCC-BY-NC-ND 4.0 International license.

a.

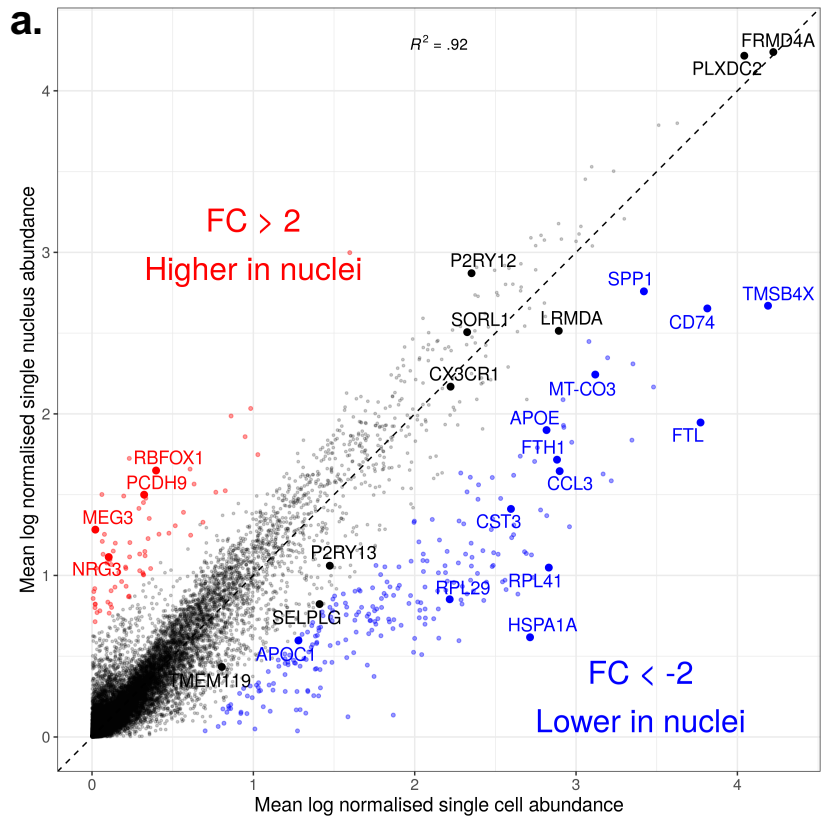

b.

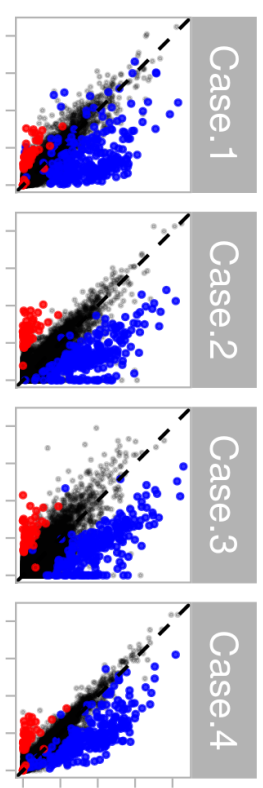

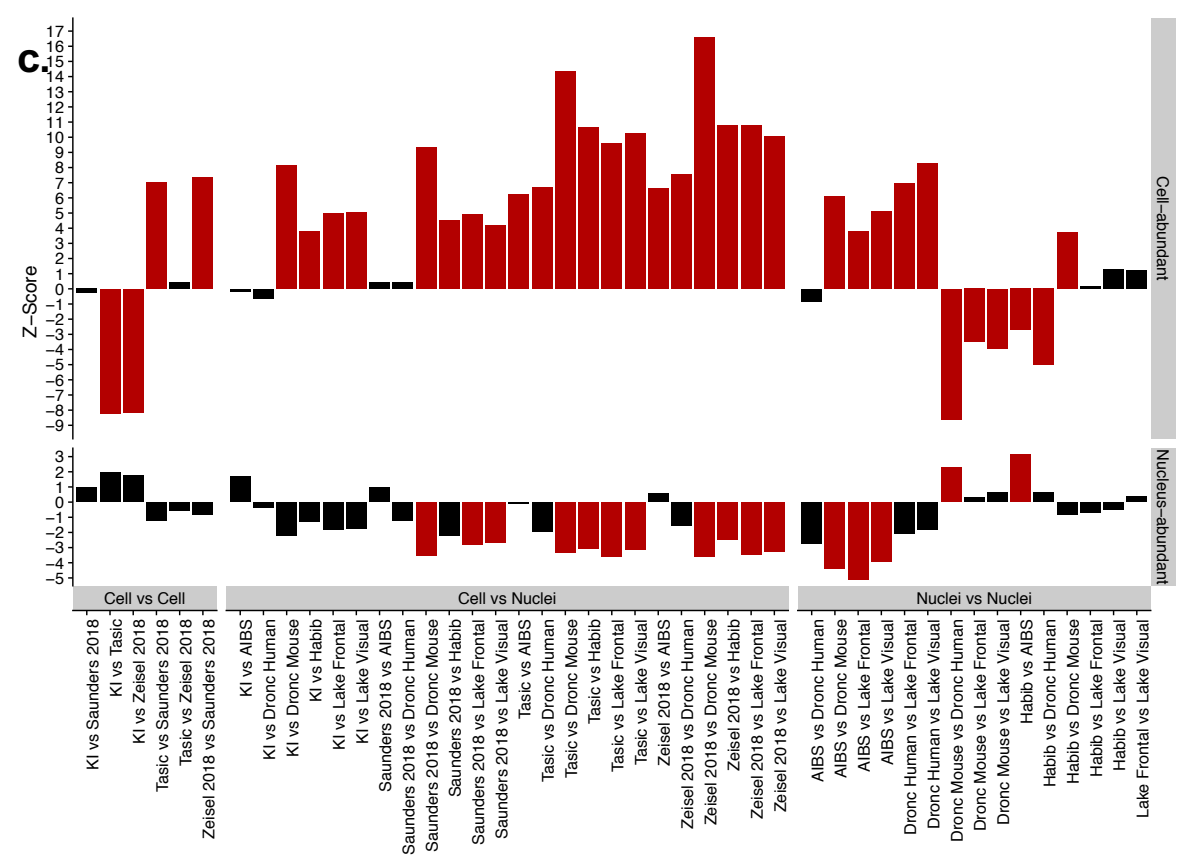


708 Fig. 2: Functional analysis of genes that are enriched or depleted in nuclei. a. Gene Set

709 Enrichment Analysis (GSEA) of gene sets related to cellular location and gene coding

710 sequence length (CDS). Background genes were ranked according to log fold change of

711 nuclei versus cells. Red: higher Normalised Enrichment Score (NES), i.e. more genes

712 associated with nuclear enrichment ; blue: negative NES scores (depletion in nuclei). ${ }^{* * *}$

713 represents significance $\left(\mathrm{p}_{\mathrm{adj}}<0.0005\right)$. $\mathrm{CDS}=$ coding sequence. $\mathbf{b}$. GSEA of super-Gene

714 Ontology gene sets against ranked nucleus-cell log fold changes. Only top and bottom

715 categories (according to NES) are shown. Colours as in a). GO = Gene Ontology ; SSU

716 RRNA = small subunit ribosomal RNA ; INF $=$ Interferon ; LC $=$ leukocyte. c. GSEA of

717 selected gene sets from previous studies of microglial activation, against fold change as in a).

$718 * * *$ represents significance $\left(\mathrm{p}_{\mathrm{adj}}<0.0005\right)$. Mic $0=$ markers of microglial cluster 0 in human

719 brain tissue ; Mic1 = markers of microglial cluster 1 (response to plaques) defined by

720 (Mathys et al., 2019) in human brain tissue. ARM = Activation Response Microglia (Sala

721 Frigerio et al. $\left.{ }^{8}\right)$. DAM = Disease-Associated Microglia (Keren-Shaul et al. $\left.{ }^{7}\right)$ d. Scatterplot as

722 in Fig. 1a), highlighting in green the DAM genes. A regression line for the highlighted genes

723 is shown in green (slope $=0.60$ ). e. Scatterplot as in $\mathrm{d}$ ), highlighting in green the ARM genes.

724 A regression line for the highlighted genes is shown in green (slope $=0.64$ ). f. Scatterplot as

725 in d), highlighting the DAM genes recovered in the study of human activation in AD (Mathys

726 et al., 2019). Purple: DAM genes not recovered in their study ; orange: DAM genes recovered

727 in their study. g. Scatterplot as in d), Green: human activation marker genes defined by

728 (Mathys et al., 2019). A regression line for the highlighted genes is shown in green (slope =

729 0.56). Gene sets are available in Supplementary Table 6. 
bioRxiv preprint doi: https://doi.org/10.1101/2020.04.13.035386; this version posted April 13, 2020. The copyright holder for this preprint

(which was not certified by peer review) is the author/funder, who has granted bioRxiv a license to display the preprint in perpetuity. It is made available under aCC-BY-NC-ND 4.0 International license.

Figure 2

a. NES

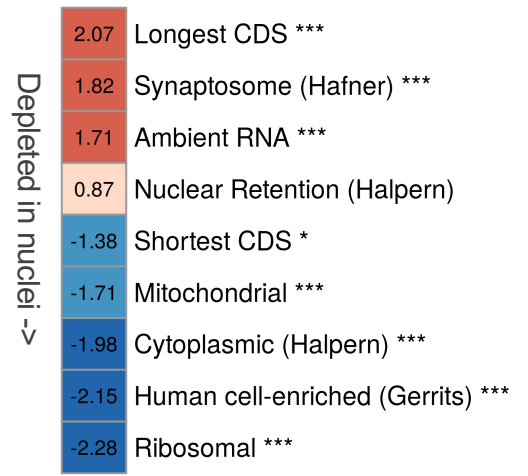

b. NES

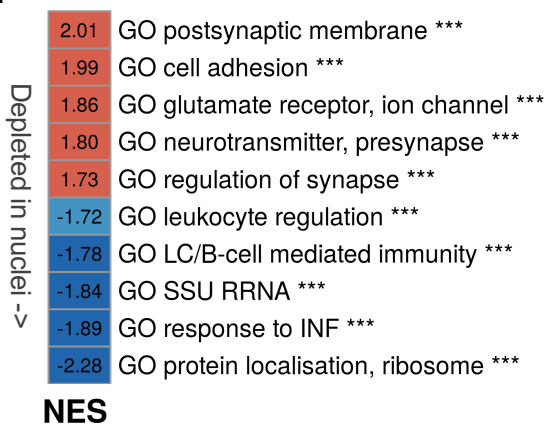

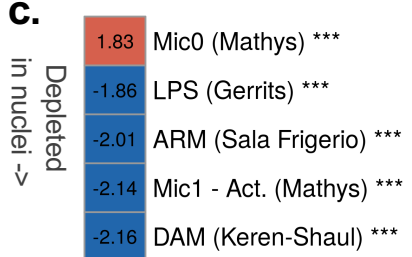

d.

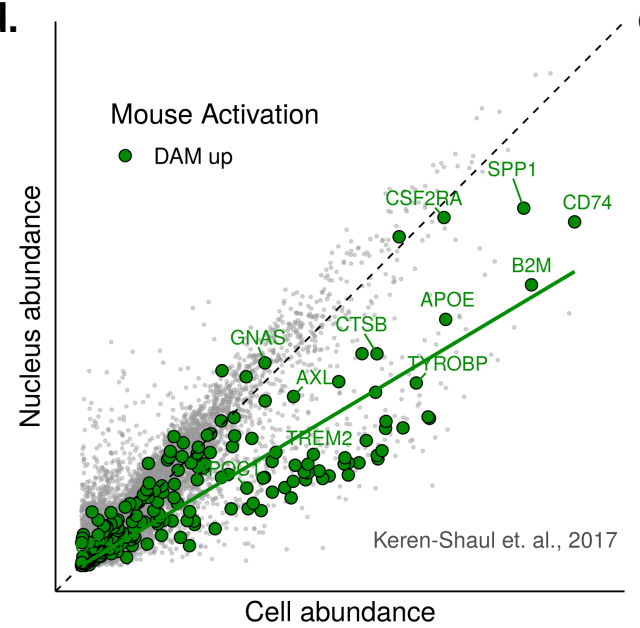

f.

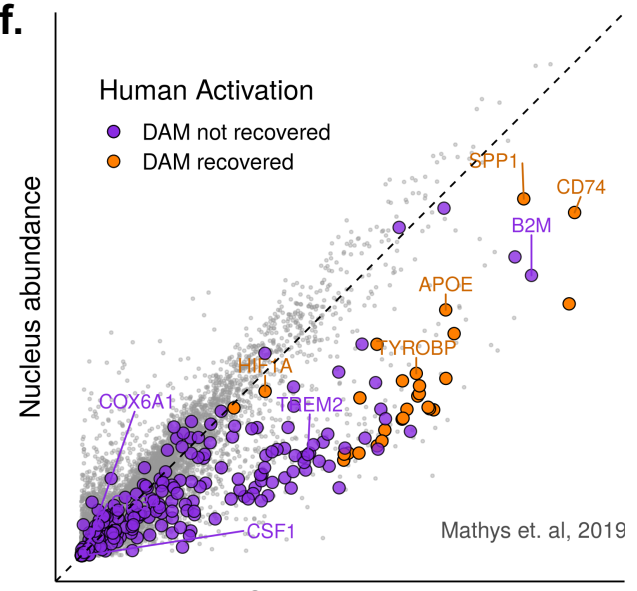

Cell abundance

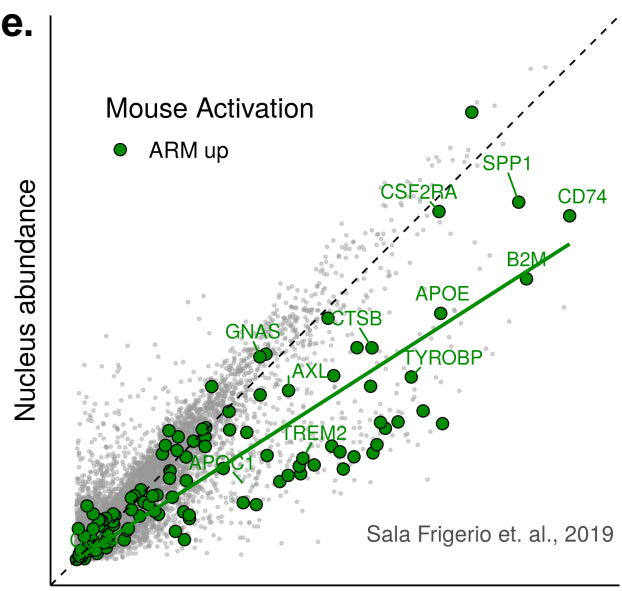

Cell abundance

g.

Human Activation

- Mic1 markers

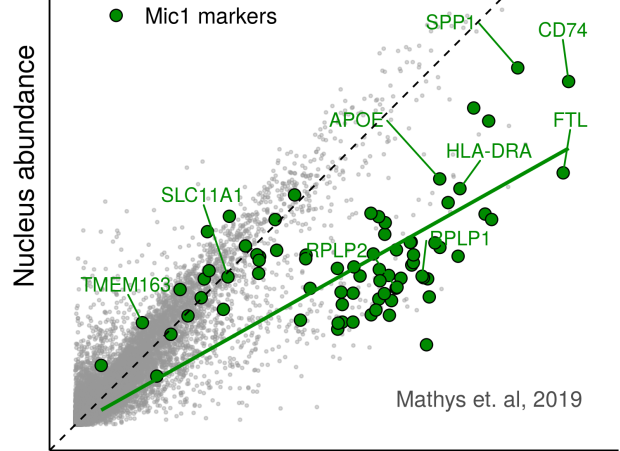

Cell abundance 


\section{Supplementary Data}

\section{Figures}

Fig. S1: Clustering of single nuclei from human cortical tissue.

Fig. S2: Gene abundance in single microglial cells versus single microglial nuclei of human cortical tissue.

\section{Text}

Supplementary Text: Clustering of microglial cells and nuclei in human cortical tissue.

\section{Tables}

Supplementary Table 1: Patient Metadata

Supplementary Table 2: Differential abundance nuclei versus cells

Supplementary Table 3: Public single cell / single nucleus datasets

Supplementary Table 4: Clustering of Gene Ontology (GO) terms

Supplementary Table 5: Results of GSEA analysis

Supplementary Table 6: Lists of all gene sets

Supplementary Table 7: Cluster markers for single nucleus cluster analysis 
730 Fig. S1: Clustering of single nuclei from human tissue. a. UMAP plot of 37,060 nuclei

731 from cortical tissue of 4 neurosurgical patients, coloured according to cell type. $\mathrm{Mg}=$

732 Microglia ; OPC $=$ oligodendrocyte precursor cells $; \mathrm{ODC}=$ oligodendrocytes $;$ Astro $=$

733 Astrocytes $;$ Endoth $=$ Endothelial cells $;$ Exc. neurons $=$ excitatory neurons. b. Violin plots

734 show selected markers of the different cell types (data is normalised for count depth and log-

735 transformed). c. UMAP plot of 3,721 microglial nuclei from cortical tissue of 4 neurosurgical

736 patients, coloured according to cluster number, after in silico extraction of microglia (based

737 on markers such as $P 2 R Y 12$ ) and reclustering. d. Module scores for gene sets extracted from

738 the original Mancuso et al. single cell microglia study (Mancuso et al., 2019). The top 40

739 genes according to log fold change were selected for each gene set. e. Overlap of top 40

740 marker genes from cellular clusters on the horizontal axis (Mancuso et al.) and nuclear

741 clusters on the vertical axis. The blue scale represents the number of genes in common,

742 numbers represent $p_{\text {adj }}$ values. Vertical coloured bars correspond to the clusters shown in c).

743 N.S. $=$ not significant $\left(p_{\text {adj }}>0.05\right)$. MS40 = Module Score of top 40 gene markers ; CAM =

744 macrophages $; \mathrm{CRM}=$ cytokine response ; in vitro $1=$ activation-like module (similar to in

745 vitro macrophages) ; in vitro 2 = activation-like module (similar to in vitro monocytes) ; in

746 vivo $\mathrm{HM}=$ homeostatic. Nuc $=$ Nuclear clusters. Cluster markers are provided in

747 Supplementary Table 7. 


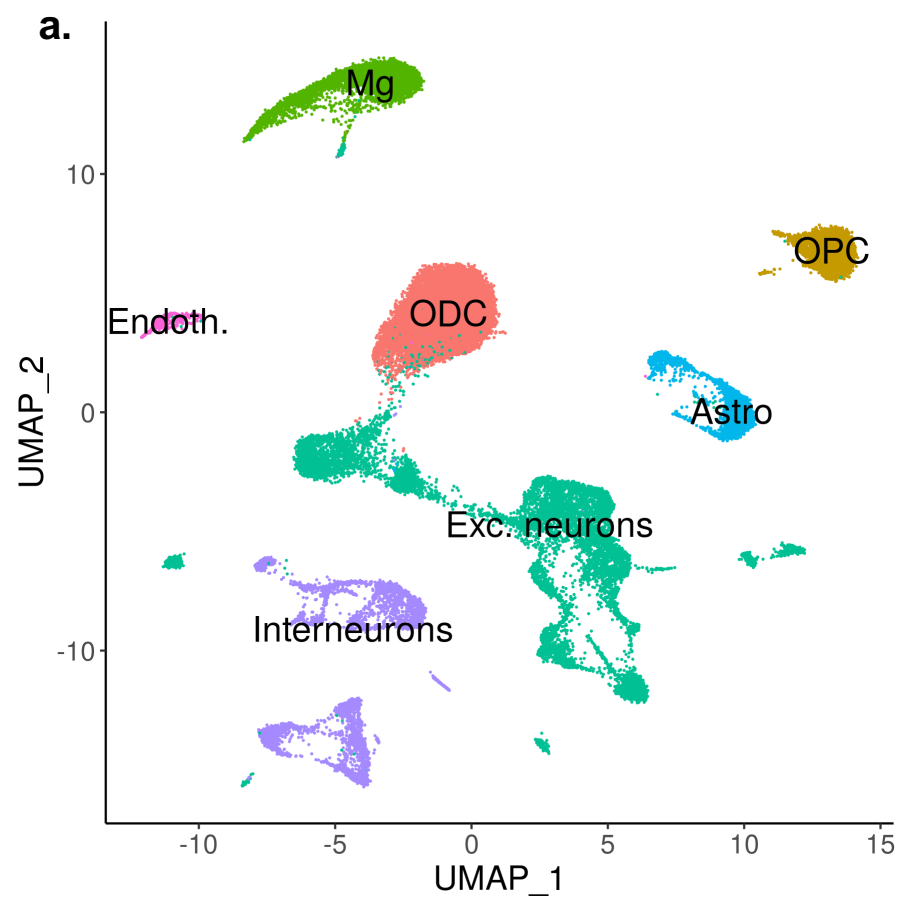

b.
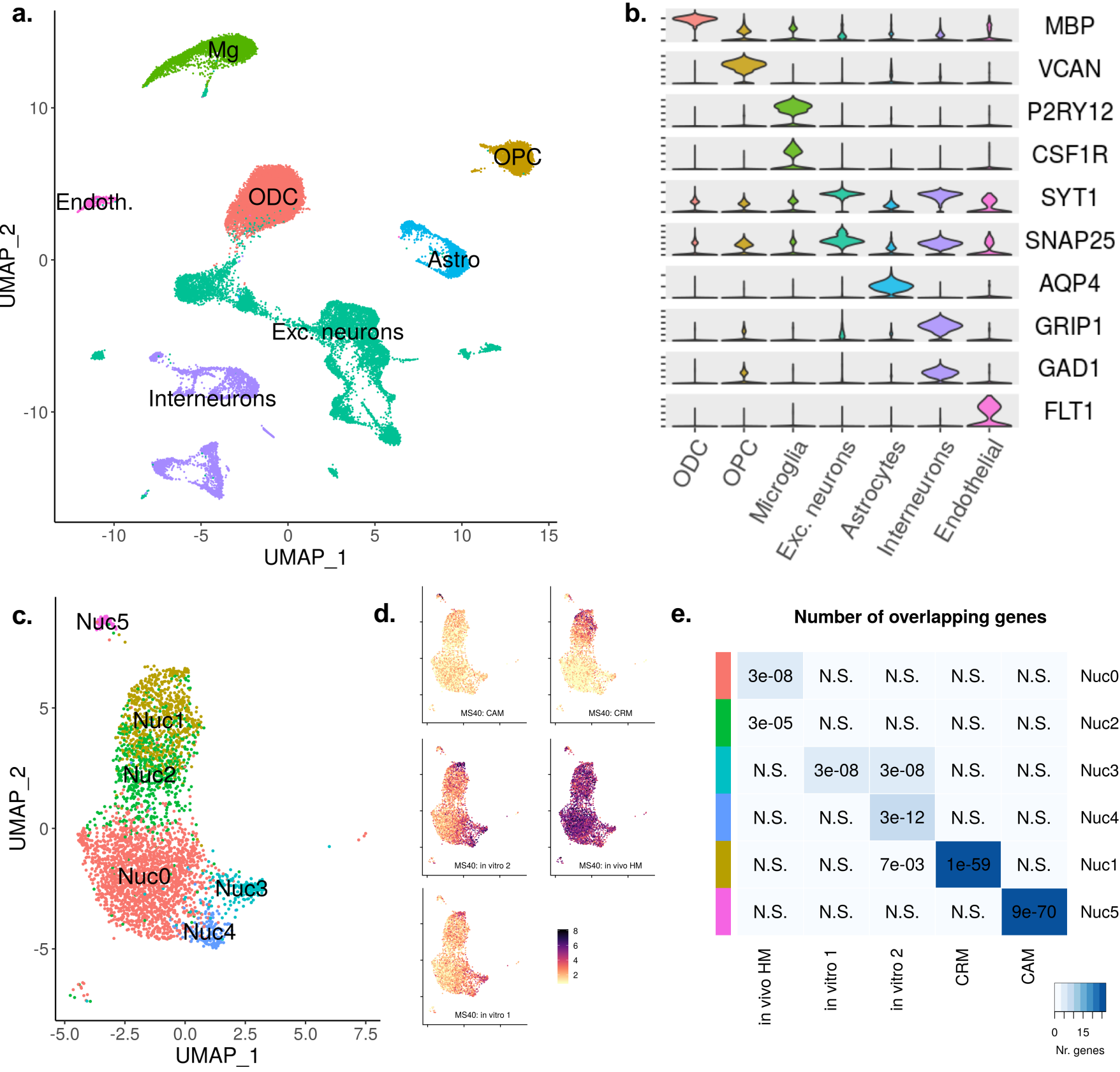

d.

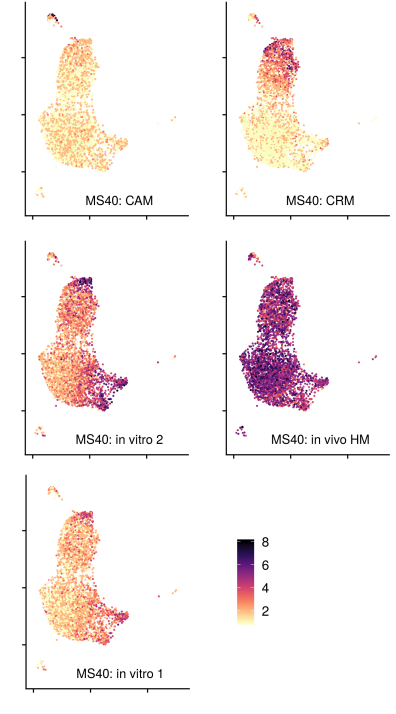

e.

Number of overlapping genes

\begin{tabular}{|c|c|c|c|c|}
\hline $3 e-08$ & N.S. & N.S. & N.S. & N.S. \\
\hline $3 e-05$ & N.S. & N.S. & N.S. & N.S. \\
\hline N.S. & $3 e-08$ & $3 e-08$ & N.S. & N.S. \\
\hline N.S. & N.S. & $3 e-12$ & N.S. & N.S. \\
\hline N.S. & N.S. & $7 e-03$ & $1 e-59$ & N.S. \\
\hline N.S. & N.S. & N.S. & N.S. & $9 e-70$ \\
\hline 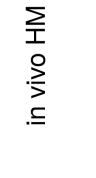 & $\begin{array}{l}\overline{0} \\
\text { 옥 } \\
\subseteq\end{array}$ & 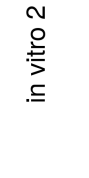 & $\sum_{\substack{0 \\
\text { Ond }}}$ & $\sum_{\delta}$ \\
\hline
\end{tabular}




\section{Fig. S2: Gene abundance in single microglial cells versus single microglial nuclei of}

751 human cortical tissue. a. Correlation matrix of gene abundance fold changes (single cell vs

752 single nucleus abundance) between patients. b. Downsampling of reads: boxplots for

753 numbers of reads (top) and numbers of genes (bottom) for single cells before downsampling,

754 single cells after downsampling, and single nuclei. Boxplots show median, with 25\% and

$75575 \%$ quantiles. c. Scatterplot of mean gene abundance in cells against mean gene abundance

756 in nuclei (as in Fig. 1a) after downsampling of reads in cells. Data is normalised to count

757 depth and log-transformed. Points in red represent genes with significantly higher abundance

758 in nuclei, while those in blue are significantly less abundant in nuclei $\left(\mathrm{p}_{\mathrm{adj}}<0.05\right.$, fold change

$759>|2|$ ). d. Scatter plot, as in Fig. 1a) showing the ambient mRNA in green (the same dataset

760 was used in Fig. 2d). Ambient RNA is defined as the 150 most abundant genes in the 700

761 nuclei with the lowest total read counts. e, f. Dendrograms of e. top 100 Gene Ontology (GO)

762 terms enriched in nuclei, and f. top $100 \mathrm{GO}$ terms depleted in nuclei. GO terms were

763 clustered based on overlap between their gene sets. The colours show how GO terms were

764 clustered. These clusters are described in Supplementary Table 4. g. Scatterplot as in Fig. 1a),

765 highlighting in green genes that are upregulated during LPS stimulation in mice (Gerrits et

766 al., 2019). A regression line for the highlighted genes is shown in green (slope $=0.78$ ). 
bioRxiv preprint doi: https://doi.org/10.1101/2020.04.13.035386; this version posted April 13, 2020. The copyright holder for this preprint (which was not certified by peer review) is the author/funder, who has granted bioRxiv a license to display the preprint in perpetuity. It is made available under aCC-BY-NC-ND 4.0 International license.

\section{Figure $\mathbf{S 2}$}

a.

\begin{tabular}{|c|c|c|c|}
\hline 1 & 0.79 & 0.62 & 0.73 \\
\hline 0.79 & 1 & 0.65 & 0.72 \\
\hline 0.62 & 0.65 & 1 & 0.88 \\
\hline 0.73 & 0.72 & 0.88 & 1 \\
\hline $\bar{u}$ & ن̈ & $\stackrel{m}{ن}$ & ִָ \\
\hline & & ha & $\begin{array}{l}\text { nge } \\
\text { betw }\end{array}$ \\
\hline
\end{tabular}

b.

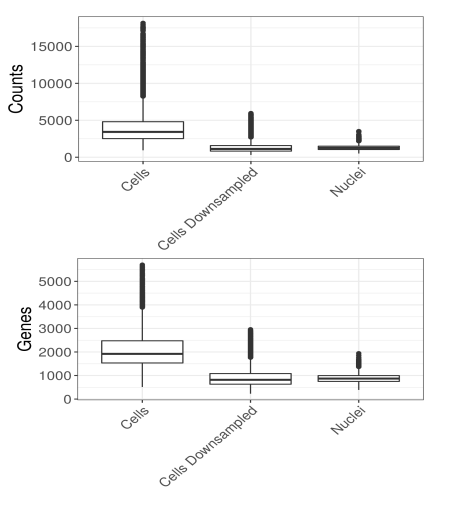

c.

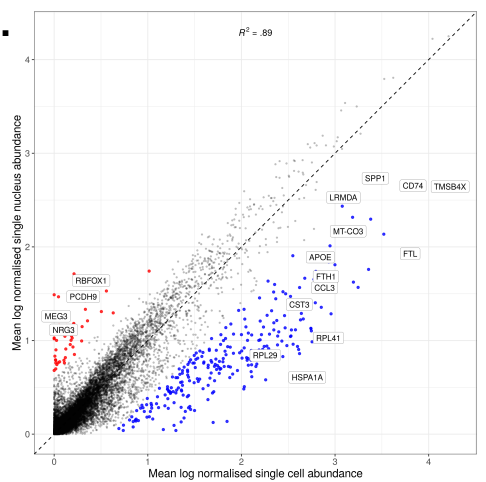

d.

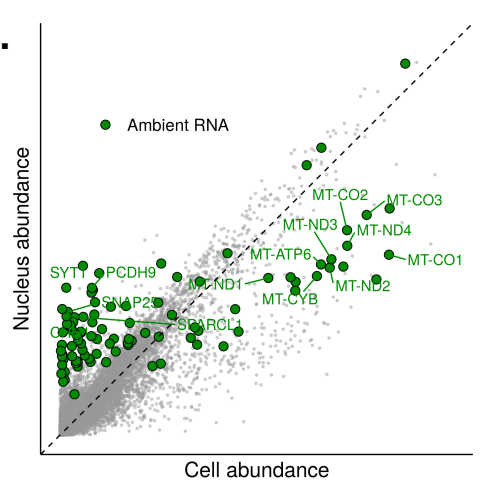

g.

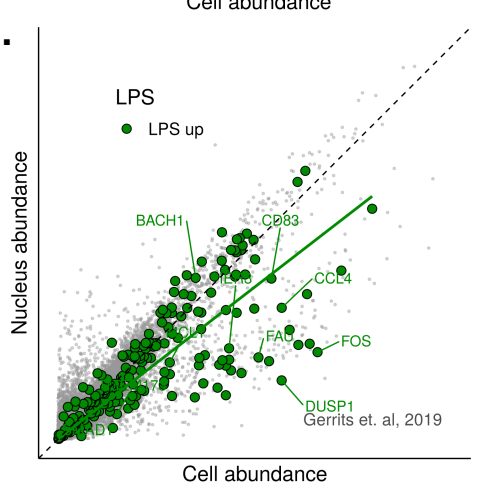

e.

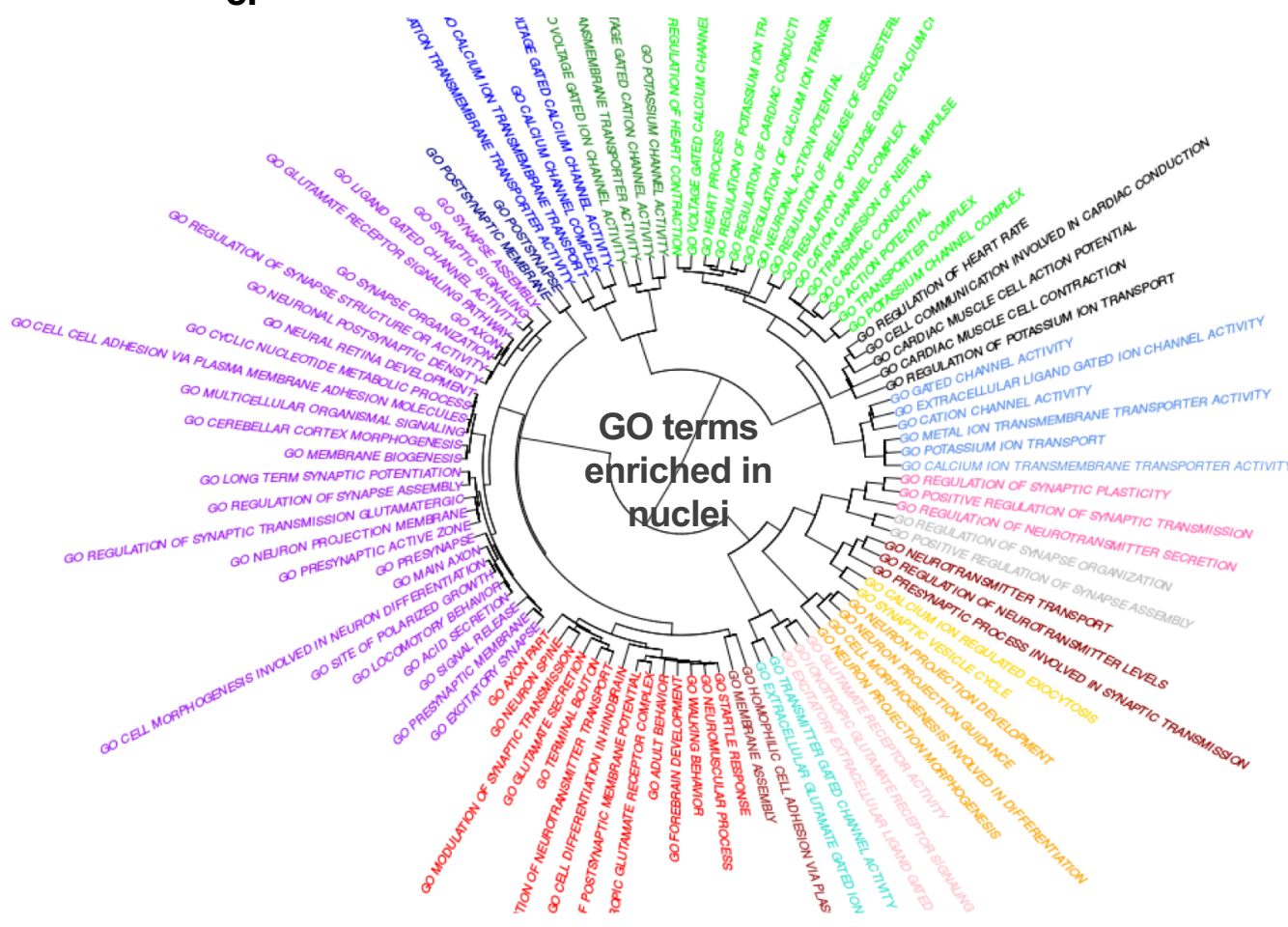

f.
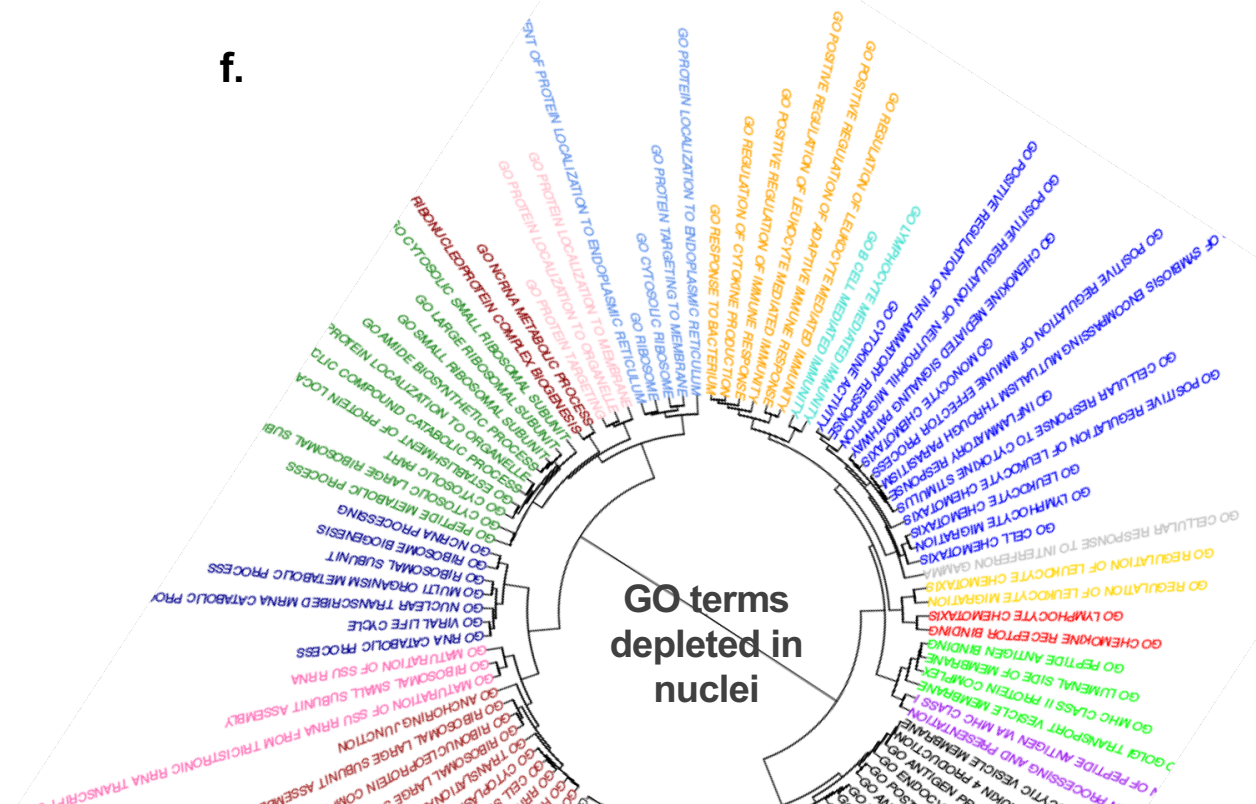
Supplementary Text: Clustering of microglial cells and nuclei in human cortical tissue

770

771 We sequenced nuclei from cortical tissue of 4 neurosurgical patients. Single cell sequencing of FAC-sorted microglia was performed on cortical tissue of the same patients in a previous study(Mancuso et al., 2019). Subject data is available in Supplementary Table 1. Following quality filtering, data integration, PCA analysis and clustering of nuclei, we identified 7 main cell types in 37,060 nuclei: oligodendrocytes (ODC, 34.0\%), excitatory neurons $(27.0 \%)$, interneurons (11.3\%), oligodendrocyte precursors (OPC 9,4\%), microglia (11.3\%), astrocytes (6.0\%), and endothelial cells (1.1\%). Supplementary Fig. 1a and Supplementary Fig. 1b show UMAP embeddings for all nuclei, coloured by cell type, and selected markers for each cell type, respectively.

Microglial nuclei were isolated and reclustered. We identified 3,721 microglia (expressing $M E F 2 A, P 2 R Y 12, C X 3 C R 1, C S F 1 R$ ), a macrophage cluster (enriched for CD163 and MRC1, 67 nuclei), a neutrophil cluster (72 nuclei), and a cluster containing microglial as well as astrocytic markers (marked by GFAP, 68 nuclei). The neutrophil and ambiguous clusters were discarded, leaving only microglia and brain macrophages for downstream analysis (Supplementary Fig. 1c). Cluster markers are provided in Supplementary Table 6.

In order to determine if nuclei could recover microglial clusters identified in cells, we selected the top 40 markers defined by Mancuso et al. (Mancuso et al., 2019) for each of the clusters they identified in the original analysis of microglial cells. For each nucleus, we scored each set of markers based on the abundance of those markers in the nucleus, using Seurat's AddModuleScore function. These scores, referred to as MS40 scores, are highlighted in Supplementary Fig. 1d. Our nuclei were able to recover a cytokine response cluster (CRM), marked by CCL3, CCL4, and an activation-like cluster, equivalent to the "in vitro microglia" identified in the original study (original markers included APOC1, GPNMB, $S P P 1, A P O E)$. Homeostatic markers appeared ubiquitously through-out the nuclei dataset, and we were not able to distinguish a reduction of these markers in the activation-like response cluster, as we would expect from transcriptomic profiling of microglia in mice

799 (Keren-Shaul et al., 2017; Sala Frigerio et al., 2019). Finally, the CAM (macrophage) cluster 
800 (CD163, MRC1), separated out from the bulk of the microglia, and was easily-recognisable

801 based on its MS40 score. Cluster markers are provided in Supplementary Table 6.

802

803 In order to quantify the differences between cells and nuclei in more detail, we examined the

804 overlap of the top 40 markers between nuclei clusters and cell clusters (Supplementary Fig.

805 1e). The cell macrophage (CAM) and cell cytokine (CRM) clusters showed the largest

806 overlaps with Nucl and Nuc7 (27 and 24 of 40 markers, respectively). Other clusters only

807 showed overlaps of between 1 and 5 genes. Cluster Nuc3 showed similar overlaps between

808 "in vitro 1" and "in vitro 2" (5 genes). Cluster Nuc0 showed an overlap of 5 genes with "in

809 vivo HM", and cluster Nuc2 showed an overlap of 2 genes with "in vivo HM". Cluster Nuc4

810 showed similarities with the "in vitro 2" cluster, suggesting it could be a cluster of activation,

811 however all 5 overlapping genes were mitochondrial genes. Cluster Nuc3 markers RPS12,

812 TPT1, FTL, RPS18 and EEF1A1 also appeared as markers of "in vitro 2".

814 We performed similar analyses using more markers, however we found that introducing more

815 markers resulted in nuclei markers overlapping with more than one cell cluster. We also

816 noticed that introducing more markers resulted in overlaps between markers of the cellular

817 clusters with each other. Selecting 40 markers allowed us to align cellular and nuclear

818 clusters in an almost one-to-one fashion (see Supplementary Fig. 1e).

820 Overall, cytokine clusters and macrophage clusters were recovered well using single nucleus

821 methods, however, differences between other microglial subpopulations were not

822 convincingly recovered. 